\title{
Beyond land application: Emerging technologies for the treatment and reuse of anaerobically digested agricultural and food waste
}

\author{
Sheets, Johnathon P. ${ }^{1}$, Liangcheng Yang ${ }^{2}$, Xumeng $\mathrm{Ge}^{1}$, Zhiwu Wang ${ }^{3}$, Yebo $\mathrm{Li}^{1 *}$ \\ ${ }^{1}$ Department of Food, Agricultural and Biological Engineering, The Ohio State University/Ohio \\ Agricultural Research and Development Center, 1680 Madison Ave., Wooster, OH 44691-4096, USA \\ ${ }^{2}$ Department of Health Sciences, Illinois State University, 324 Felmley Hall, Normal, IL 61790, USA \\ ${ }^{3}$ The Ohio State University ATI, 1328 Dover Rd, Wooster, OH 44691, USA \\ * Corresponding author. Phone: +1 330263 3855. E-mail li.851@ osu.edu
}

\begin{abstract}
\end{abstract}
Effective treatment and reuse of the massive quantities of agricultural and food wastes generated daily has the potential to improve the sustainability of food production systems. Anaerobic digestion (AD) is used throughout the world as a waste treatment process to convert organic waste into two main products: biogas and nutrient-rich digestate, called AD effluent. Biogas can be used as a source of renewable energy or transportation fuels, while AD effluent is traditionally applied to land as a soil amendment. However, there are economic and environmental concerns that limit widespread land application, which may lead to underutilization of $\mathrm{AD}$ for the treatment of agricultural and food wastes. To combat these constraints, existing and novel methods have emerged to treat or reuse AD effluent. The objective of this review is to analyze several of the emerging methods used for efficient treatment and reuse of $\mathrm{AD}$ effluent. Overall, the application of emerging techniques is limited by $\mathrm{AD}$ effluent composition, especially the total solids content. Some technologies such as composting, use the solid fraction of $\mathrm{AD}$ effluent, while most other technologies, such as algae culture and struvite crystallization, use the liquid fraction. Therefore, dewatering of AD effluent, reuse of the liquid and solid fractions, and land application could all be combined to sustainably manage the large quantities of AD effluent produced. Issues such as pathogen regrowth and prevalence of emerging organic micro-pollutants are also discussed.

Keywords: anaerobic digestion, land application, AD effluent, resource recovery, food waste, agricultural waste 
1 Contents

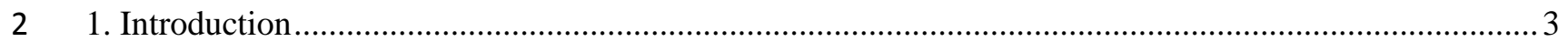

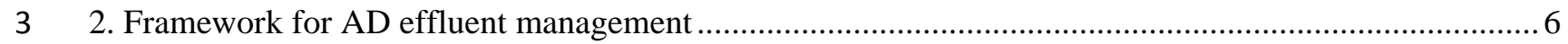

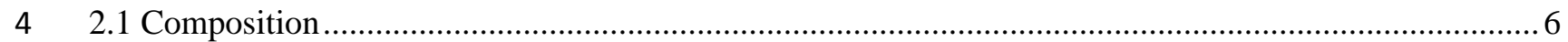

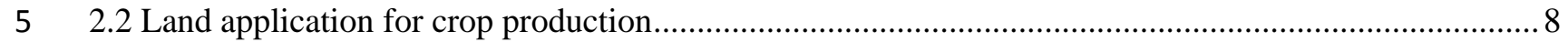

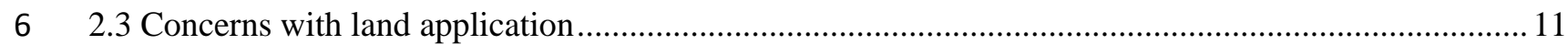

7 3. Emerging techniques for treatment and reuse of raw AD effluent ................................................... 12

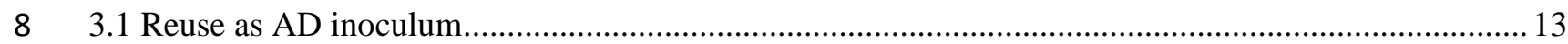

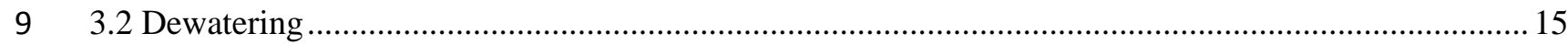

10 4. Emerging techniques for management of the liquid fraction of $\mathrm{AD}$ effluent ..................................... 16

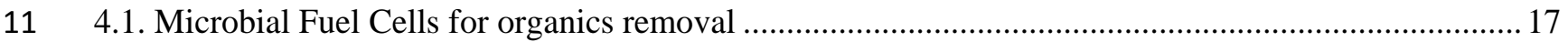

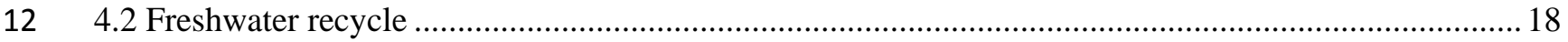

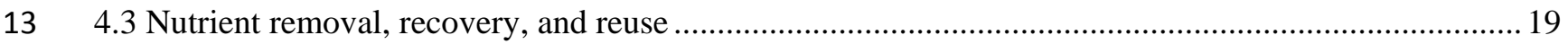

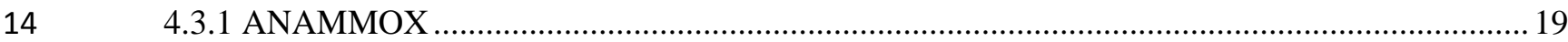

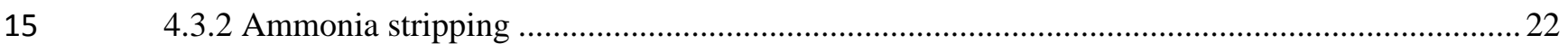

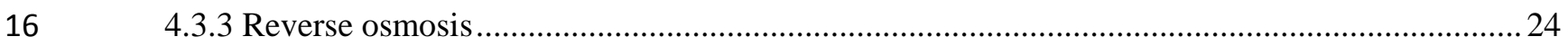

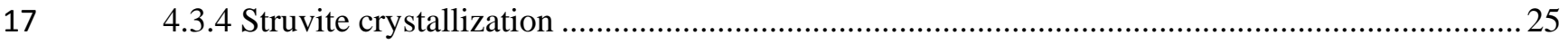

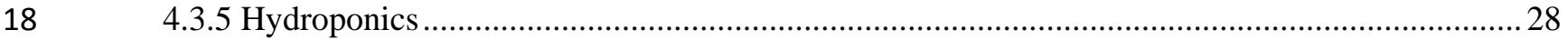

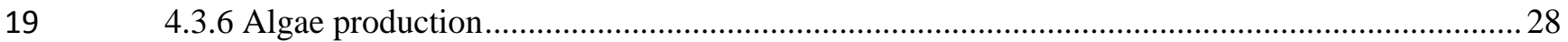

20 5. Emerging techniques for reuse of the solid fraction of $\mathrm{AD}$ effluent ................................................. 32

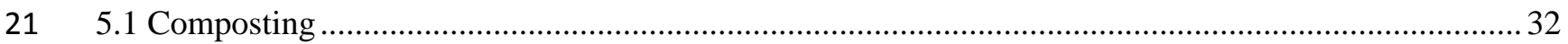

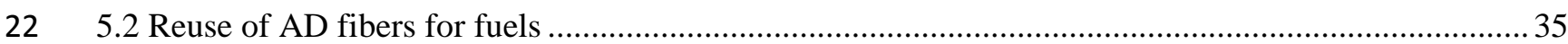

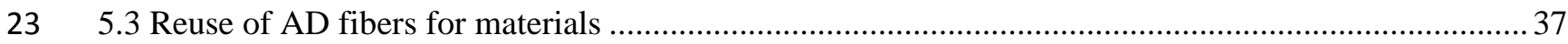

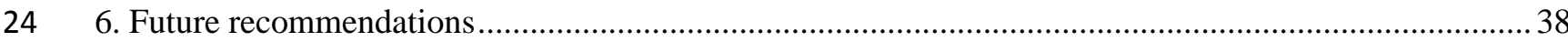

$25 \quad 6.1$ Emerging organic pollutants and treatment techniques ................................................................ 38

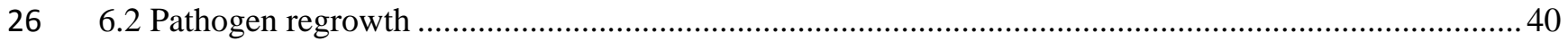

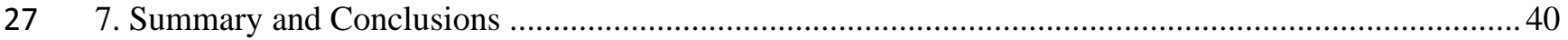



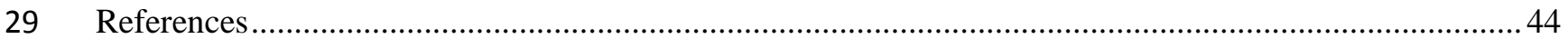




\section{Introduction}

In the United States, more than 300 million tons of organic wastes are generated each year from

agricultural and food processing industries $[1,2]$. Sustainable treatment of these huge amounts of organic wastes has become a global challenge. Anaerobic digestion (AD) has been used throughout the world to stabilize food wastes, manure and other organic wastes through volatile solids (VS) mineralization and pathogen reduction [3]. Additionally, AD has gained recognition for its added benefit of producing renewable energy. During the AD process, anaerobic microorganisms convert organic matter into biogas and digestate (called AD effluent). The biogas, made up of mainly methane ( $60 \%)$ and carbon dioxide ( 40\%), can be used to produce heat, electricity, compressed natural gas (CNG), and/or liquefied natural gas (LNG) [4]. Meanwhile, the nutrient-rich AD effluent is commonly used as an organic fertilizer [5]. Recently, increasing attention has been paid to $\mathrm{AD}$ due to its capability to produce bioenergy from a broad range of feedstocks, including agricultural residues and forestry wastes [3].

In the U.S., there are $247 \mathrm{AD}$ systems in operation at commercial livestock facilities [6]. It is estimated that 8,200 livestock facilities could benefit from AD [7]. There are even fewer AD systems dedicated for food waste, which contributes over $12 \%$ of the organic waste produced in the U.S [1, 8].

One reason for underutilization of $\mathrm{AD}$ could be the low price of electricity, which reduces the economic incentive to use AD for energy production. For example, Yiridoe et al. [9] estimated that large livestock operations (600 dairy cows or 800 sows) are required to make an on-farm $\mathrm{AD}$ system economically feasible. The expanding world population will increase the demand for agricultural and food products, causing increased quantities of organic wastes, increasing the potential for AD application and, consequentially, the quantities of $\mathrm{AD}$ effluent. The difficulty in treating and reusing large quantities of $\mathrm{AD}$ effluent is another likely cause of underutilization of AD technology [10]. The most common AD effluent treatment is land application for crop production, because large quantities can be spread over large areas of farmland [5]. However, improper land application practices can lead to ammonia volatilization, pathogen contamination, over-fertilization and nutrient runoff, sparking considerable 
debate about the environmental sustainability of this practice [5]. To improve economic and environmental sustainability of $\mathrm{AD}$, alternative methods for $\mathrm{AD}$ effluent management are desirable.

Many existing technologies, such as ammonia stripping, composting, reverse osmosis and struvite crystallization, have been used for treatment and reuse of other wastes, including digested sewage sludge and municipal wastewater $[11,12]$. Recently, these techniques have emerged as effective methods for high throughput treatment of AD effluent [13-16]. Many emerging methods (algae production, hydroponics, freshwater source for ethanol production) can reuse the water and nutrients (nitrogen and phosphorus) present in the liquid fraction of $\mathrm{AD}$ effluent [17-19]. Additionally, fibers in the solid fraction can be effectively reused for the production of fuels, particleboard, and bedding materials [20-22]. Integration of emerging technologies with responsible land application practices could improve the economic feasibility and environmental sustainability for the AD of food and agricultural wastes. The objective of this study was to analyze emerging solutions for management of the water, solids, organic matter, and nutrients in AD effluent. Effluent from anaerobic digesters used for municipal wastewater treatment is outside of the scope of this review. However, many management techniques developed for municipal anaerobic digester effluent, such as composting and struvite crystallization, can be applied to food waste/agricultural waste $\mathrm{AD}$ effluent, and are summarized in the designated sections of this review.

Figure 1 outlines a proposed process for the reuse and treatment of AD effluent using currently available technologies. In this process, a portion of $\mathrm{AD}$ effluent is land applied for crop production. Meanwhile, other portions are reused as AD inoculum or dewatered to produce a liquid and solid fraction. The liquid fraction of AD effluent may be used as a freshwater source for ethanol production. Concurrently, a portion of the liquid fraction can be sent to microbial fuel cells, which degrade residual organics and produce sustainable electricity. Meanwhile, nitrogen in the liquid fraction can be removed by ANAMMOX and/or recovered as ammonium sulfate $\left(\left(\mathrm{NH}_{4}\right)_{2} \mathrm{SO}_{4}\right)$ by ammonia stripping and absorption. Additionally, both the nitrogen and phosphorus in the liquid fraction can be used for algae/ hydroponic plant production or converted to struvite, a renewable magnesium ammonium phosphate fertilizer. The solid fraction of $\mathrm{AD}$ effluent can be composted with lignocellulosic biomass, converted into 
1 fuel by pyrolysis, used for energy and ash in concrete manufacturing, utilized for particleboard, animal

2 bedding, or hydrolyzed and fermented into cellulosic ethanol. Overall, the processes outlined in Figure 1

3 could be environmentally friendly and cost effective options for treating AD effluent. Consequently,

4 application of these methodologies could promote more widespread adoption of AD for the treatment of 5 agricultural and food wastes.




Figure 1: Proposed processes for beneficial reuse and treatment of AD effluent

\section{Framework for AD effluent management}

\subsection{Composition}

A recent compositional analysis of $\mathrm{AD}$ effluent used for agronomic land application is summarized in Table 1. The composition of AD effluent is mainly dependent on feedstock components and $\mathrm{AD}$ operating conditions (e.g. temperature, retention time). $\mathrm{AD}$ effluent is usually analyzed for dry matter (\% DM) or total solids (\% TS); organic matter (\% OM) or volatile solids (\% VS); total carbon (TC); total nitrogen (TN); total ammonia nitrogen (TAN); total phosphorus (TP); total potassium (TK); sulfur (S); minor nutrients, such as magnesium $(\mathrm{Mg})$ and calcium $(\mathrm{Ca})$; heavy metals $(\mathrm{As}, \mathrm{Cd}, \mathrm{Cr}, \mathrm{Cu}$ ,Hg, Mn, Ni, Pb, Zn); pathogens (commonly using fecal coliforms as an indicator); chemical oxygen demand (COD); and biochemical oxygen demand (BOD) [23].

Table 1: AD effluent composition from digesters feeding food waste or agricultural feedstock

\begin{tabular}{|c|c|c|c|c|c|}
\hline & \multirow[b]{2}{*}{ Component and unit } & \multicolumn{4}{|c|}{ Feedstock } \\
\hline & & Food Waste $^{\mathrm{a}}$ & Reference(s) & $\begin{array}{c}\text { Agricultural } \\
\text { feedstock }^{\mathbf{b}}\end{array}$ & Reference(s) \\
\hline \multirow{11}{*}{ Fertilizer Properties } & $\mathrm{pH}$ & $7.9-8.2$ & [24-27] & $7.5-8.4$ & {$[28-31]$} \\
\hline & $\mathrm{DM}(\%)$ & $1.4-6.1$ & {$[24-27,32,33]$} & $7.4-24.0$ & {$[28-31,34]$} \\
\hline & VS ( $\%$ of DM) & $38-71$ & {$[24,26,32,33]$} & 69-74 & \\
\hline & $\mathrm{TC}\left(\mathrm{g} \mathrm{kg}^{-1} \mathrm{DM}\right)$ & $311-452$ & [24-26] & $300-400$ & {$[28-31]$} \\
\hline & $\mathrm{TN}\left(\mathrm{g} \mathrm{kg}^{-1} \mathrm{DM}\right)$ & $112-157$ & {$[24-27,32,33]$} & $22-88$ & {$[28-31,34,35]$} \\
\hline & TAN $\left(\mathrm{g} \mathrm{kg}^{-1} \mathrm{DM}\right)$ & $52-108$ & {$[24-27,32]$} & $6-45$ & {$[28-31,34,35]$} \\
\hline & $\mathrm{TP}\left(\mathrm{g} \mathrm{kg}^{-1} \mathrm{DM}\right)$ & $6-16$ & {$[24,25,27,32,33]$} & $2-66$ & $\begin{array}{c}{[28,30,31,34} \\
35]\end{array}$ \\
\hline & $\mathrm{TK}\left(\mathrm{g} \mathrm{kg}^{-1} \mathrm{DM}\right)$ & $26-81$ & {$[24,25,27,32,33]$} & $9-100$ & $\begin{array}{c}{[28,30,31,34} \\
35]\end{array}$ \\
\hline & $\mathrm{S}\left(\mathrm{g} \mathrm{kg}^{-1} \mathrm{DM}\right)$ & $6-10$ & {$[24,25,27]$} & - & NR \\
\hline & $\mathrm{Mg}\left(\mathrm{g} \mathrm{kg}^{-1} \mathrm{DM}\right)$ & $3-10$ & {$[24,25,27]$} & - & NR \\
\hline & $\mathrm{Ca}\left(\mathrm{g} \mathrm{kg}^{-1} \mathrm{DM}\right)$ & $10-52$ & {$[25,27]$} & 31 & {$[31]$} \\
\hline \multirow[t]{2}{*}{ Wastewater constituents } & $\mathrm{BOD}\left(\mathrm{mg} \mathrm{L}^{-1}\right)$ & NR & - & 5900 & {$[29,30]$} \\
\hline & $\mathrm{COD}\left(\mathrm{mg} \mathrm{L}^{-1}\right)$ & NR & - & 5600 & [34] \\
\hline \multirow{9}{*}{ Heavy metals } & As $\left(\mathrm{mg} \mathrm{kg}^{-1} \mathrm{DM}\right)$ & NR & - & 29 & {$[36]$} \\
\hline & $\mathrm{Cd}\left(\mathrm{mg} \mathrm{kg}^{-1} \mathrm{DM}\right)$ & $0.3-1.0$ & {$[25,32]$} & $0-10$ & {$[30,36,37]$} \\
\hline & $\mathrm{Cr}\left(\mathrm{mg} \mathrm{kg}^{-1} \mathrm{DM}\right)$ & $13-29$ & {$[25,32]$} & $2-55$ & {$[30,36,37]$} \\
\hline & $\mathrm{Cu}\left(\mathrm{mg} \mathrm{kg}^{-1} \mathrm{DM}\right)$ & $14-70$ & {$[25,27,32]$} & $1-1373$ & {$[31,36,37]$} \\
\hline & $\mathrm{Hg}\left(\mathrm{mg} \mathrm{kg}^{-1} \mathrm{DM}\right)$ & $<0.1$ & {$[25]$} & ND & [37] \\
\hline & $\mathrm{Mn}\left(\mathrm{mg} \mathrm{kg}^{-1} \mathrm{DM}\right)$ & $0-201$ & {$[25,27]$} & NR & - \\
\hline & $\mathrm{Ni}\left(\mathrm{mg} \mathrm{kg}^{-1} \mathrm{DM}\right)$ & $25-39$ & {$[25,32]$} & $2-36$ & {$[30,36,37]$} \\
\hline & $\mathrm{Pb}\left(\mathrm{mg} \mathrm{kg}^{-1} \mathrm{DM}\right)$ & $0.1-10$ & {$[25,32]$} & $0-46$ & {$[30,36,37]$} \\
\hline & $\mathrm{Zn}\left(\mathrm{mg} \mathrm{kg}^{-1} \mathrm{DM}\right)$ & $113-474$ & {$[25,27,32]$} & $43-3884$ & {$[31,36,37]$} \\
\hline
\end{tabular}

16 a food wastes include food slurry, slaughterhouse wastes, source separated household wastes, and kitchen and garden wastes; ${ }^{\mathrm{b}}{ }^{\mathrm{aggricultural}}$ 17 feedstock includes manures, silage, and crop residues; $\mathrm{NR}=$ not reported; ND=not detected 
$\mathrm{AD}$ operations and feedstock characteristics clearly impact the DM content, with values between $1 \%$ and 24\% (Table 1); however, typical DM contents of AD effluent produced during commercial AD of animal manures and food wastes ranged from 2-9\% [25, 28, 30]. During the AD process, organic nitrogen

4 in feedstock is degraded, but only very little is assimilated by AD microorganisms [3]. As a result, AD

5 effluent usually contains high levels of TN (up to $157 \mathrm{~g} \mathrm{TN} \mathrm{kg}^{-1} \mathrm{DM}$ ) which is mostly TAN (50-99\%), a

6 combination of ammonium $\left(\mathrm{NH}_{4}^{+}\right)$and free ammonia $\left(\mathrm{NH}_{3}\right)$ [28]. The ratio of $\mathrm{NH}_{4}{ }^{+}$to $\mathrm{NH}_{3}$ varies with

$7 \mathrm{pH}$ and temperature according to ion dissociation balance. The carbon to nitrogen $(\mathrm{C} / \mathrm{N})$ ratio is usually

8 used as an indicator to assess the applicability of AD effluent as an amendment to a specific soil type. The

9 change in $\mathrm{C} / \mathrm{N}$ ratio is dependent on feedstock carbon degradability, because the nitrogen content is

10 relatively stable in AD [38]. The phosphorus content comes from adenylates, nucleic acids and

11 phospholipids, which are in the feedstocks [38]. The $\mathrm{pH}$ (7.5-8.0) in AD effluent increases the solubility

12 of phosphate $\left(\mathrm{PO}_{4}{ }^{3-}\right)$, causing precipitation into calcium or magnesium phosphates $\left(\mathrm{Ca}_{3}\left(\mathrm{PO}_{4}\right)_{2}\right.$ or

$\left.13 \mathrm{Mg}_{3}\left(\mathrm{PO}_{4}\right)_{2}\right)$ and struvite, a complex crystal that contains nitrogen, phosphorus, and magnesium (Section

14 4.3.4) [38]. The sulfur (S) enters digesters from feedstock proteins, and over supply can lead to hydrogen

15 sulfide $\left(\mathrm{H}_{2} \mathrm{~S}\right)$ production, which negatively affects biogas quality [38, 39]. Heavy metals in AD effluent

16 have been predicted to originate in commercial animal feeds and AD seeding sludge [37]. However, the

17 concentrations of heavy metals in Table 1 are well below the ceiling concentration limits for land

18 application set by the U.S EPA [40]. None of the studies measured pathogen levels in AD effluent prior to

19 land application. To ensure protection of public and animal health, future studies should also monitor

20 pathogens prior to land application [41].

As mentioned earlier, feedstock variability and digester operating parameters affect the

22 composition of AD effluent, making generalized statements about composition very difficult [5]. For

23 example, mesophilic $\mathrm{AD}\left(37^{\circ} \mathrm{C}\right)$ of feedstocks with high levels of $\mathrm{TN}$ and degradable organics produces

$24 \mathrm{AD}$ effluent with high TAN and a low $\mathrm{C} / \mathrm{N}$ ratio [38]. Additionally, thermophilic $\mathrm{AD}\left(55^{\circ} \mathrm{C}\right)$ can increase 25 pathogen and VS destruction [42], producing effluent with safer amendment properties and lower C/N 
ratios, respectively. Still, the nitrogen to phosphorus (N/P) ratio is relatively stable in AD effluent [38].

2 This fact has prompted the use of AD effluent as an organic fertilizer for the production of crops.

3

4

\subsection{Land application for crop production}

As shown in Table 2, several crops including maize, silage [31], ryegrass [28], legumes [43], and fruits [44] have been successfully grown using AD effluent as an organic fertilizer. The local climate, physical and biological soil properties, AD effluent composition, nitrogen application rates, plantavailable nitrogen, crop type, and crop rotations substantially affected plant yield and nitrogen uptake. For example, Sieling et al. [45] studied the nitrogen balance during a three year crop rotation using digested manure and raw manure as organic fertilizers as well as mineral fertilizers. Overall, grass yields and nitrogen uptake were lower when digested manure was used, but there was higher nitrogen balance (difference between nitrogen fertilization and plant nitrogen uptake) than for the mineral fertilizer or raw manure [45]. Svensson et al. [46] compared land application of compost and AD effluent, both from source-separated domestic wastes, and concluded that the composts needed nitrogen supplementation while AD effluent needed phosphorus supplementation in order to maintain grain quality and yields [46]. Generally, crop yields and nitrogen uptake for experiments conducted in pots have been similar using AD effluents, organic fertilizers, and inorganic fertilizers. For example, Walsh et al. [47] showed that grass yields were comparable in 1.2-L pots using liquid $\mathrm{AD}$ effluent, mineral fertilizers, and other organic fertilizers. This was attributed to the broad nutrient base within AD effluent [47]. Haraldsen et al. [27] showed that barley production and nutrient uptake rates were comparable between household waste AD effluent and inorganic fertilizer for applications with equivalent amounts of nitrogen. Bougnom et al. [43] showed that the combination of AD effluent and ash was a good soil amendment for grass, herbs, and leguminous plant production, because the amendment did not significantly affect the acidic soil's physical and chemical properties [43]. Abubaker et al. [25] showed that wheat yields were similar when using AD effluent or mineral fertilizers. An additional advantage was that the AD effluent actually increased the nitrogen mineralization capacity and partial ammonia oxidation rate in the soil [25]. Fouda et al. [28] tested several AD effluents and showed that ryegrass efficiently utilized nitrogen (80-100\%) for all of 
them. The nitrogen balance was correlated to the amount of organic nitrogen applied, and the authors

2 concluded the organic C/organic $\mathrm{N}$ ratio should be low to maintain good short-term nitrogen availability

3 [28]. Similarly, phosphorus uptake by maize (Zea mays L.) was comparable when Bachmann et al. [48]

4 used digested dairy slurry and maize silage, raw dairy slurry, or mineral fertilizers. Interestingly, Yu et al.

5 [44] grew tomatoes in AD effluent, concentrated AD effluent, and traditional fertilizers. Their results

6 showed that 16 kinds of amino acids, protein, beta-carotene, soluble sugar, vitamin C, and tannins

7 increased after application of concentrated AD effluent.

8 Field scale results have also been promising. In a three-year study, Gagnon et al. [31] land

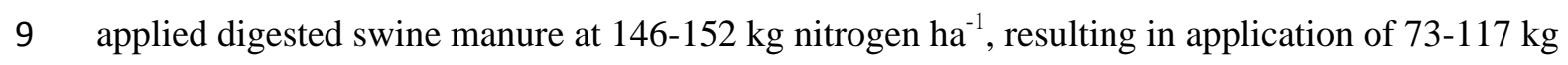

10 phosphorus $\mathrm{ha}^{-1}$. Similar corn silage yields were observed with either digested manure or undigested

11 manure. However, crop nitrogen utilization from the organic fertilizers was only $70 \%$ as efficient as crops

12 using mineral nitrate fertilizers [31]. Loria et al. [49] showed that digested and raw swine manure were

13 not significantly different as a source of nitrogen for growing corn. This result was attributed to similar

14 grain yields and plant nitrogen uptake, despite variable weather conditions. In another example, Möller et

15 al. [50] showed that yields of several crops were not significantly different between raw and digested

16 animal slurry. Additionally, Chantigny et al. [51] concluded that digested liquid swine manure had similar

17 fertilizer value to mineral fertilizers based on similar grain yields $\left(6-11 \mathrm{t} \mathrm{ha}^{-1}\right)$, nitrogen uptake $(83-176 \mathrm{~kg}$

$\left.18 \mathrm{ha}^{-1}\right)$, and phosphorus uptake (19-40 $\left.\mathrm{kg} \mathrm{ha}^{-1}\right)$, and attributed the results to land application practices that

19 limited ammonia volatilization (Section 2.3). All this evidence points to the fact that AD effluent can be

20 applied as an effective organic fertilizer for agricultural crop growth. However, no studies have examined

21 the effects of $\mathrm{AD}$ operational parameters on $\mathrm{AD}$ effluent composition, studied the long term effects of $\mathrm{AD}$

22 effluent on physical and biological soil properties, nor examined nutrient mass balance and energy

23 balances at field scale levels. Evaluation of these factors could provide better understanding of the

24 impacts of land application [5]. There are several additional concerns that must be addressed, including

25 pathogen exposure, nutrient runoff, and transport economics. These issues have limited the widespread

26 adoption of AD effluent land application. 
Table 2: Crop production using AD effluent as nitrogen fertilizer

\begin{tabular}{|c|c|c|c|c|c|c|c|}
\hline AD feedstock & $\begin{array}{c}\text { Application Rate } \\
\left(\mathrm{kg} \mathrm{N} \mathrm{ha}^{-1}\right)\end{array}$ & Crop & Time Period & Plot Area & DM Yield & $\begin{array}{c}\text { N uptake } \\
\left(\mathrm{kg} \mathrm{N} \mathrm{ha}^{-1}\right)\end{array}$ & Reference \\
\hline Dairy slurry & $100,50^{\mathrm{a}}$ & Ryegrass & $16 \mathrm{wk}$ & $0.018 \mathrm{~m}^{2} \operatorname{pot}^{-1}$ & $4-6 \mathrm{~g} \mathrm{pot}^{-1}$ & NR & [47] \\
\hline Dairy slurry & $100,50^{\mathrm{a}}$ & Ryegrass/clover & $16 \mathrm{wk}$ & $0.018 \mathrm{~m}^{2} \operatorname{pot}^{-1}$ & $4-8 \operatorname{g~pot}^{-1}$ & NR & [47] \\
\hline Slaughterhouse waste & $35-140^{\mathrm{b}}$ & Wheat & $77 \mathrm{~d}$ & $0.020 \mathrm{~m}^{2}$ pot $^{-1}$ & $5-25$ g pot $^{-1}$ & NR & [25] \\
\hline $\begin{array}{l}\text { Dairy slurry/maize silage/wheat } \\
\text { grain }\end{array}$ & $1.13^{\mathrm{c}}$ & Maize & $8 \mathrm{wk}$ & $0.035 \mathrm{~m}^{2} \operatorname{pot}^{-1}$ & $59-65 \mathrm{~g} \mathrm{pot}^{-1}$ & $0.451-0.512^{\mathrm{c}}$ & [48] \\
\hline Household waste & 80,160 & Barley & $103 \mathrm{~d}$ & $0.036 \mathrm{~m}^{2} \operatorname{pot}^{-1}$ & 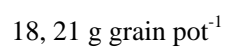 & $0.18,0.28^{\mathrm{c}}$ & [27] \\
\hline Maize silage/cattle manure & $0.3^{\mathrm{c}}$ & Ryegrass & $309 \mathrm{~d}$ & $0.05 \mathrm{~m}^{2}$ pot $^{-1}$ & NR & $1.3-1.6^{\mathrm{c}}$ & [28] \\
\hline $\begin{array}{c}\text { Maize silage/poultry } \\
\text { manure/unidentified slurry }\end{array}$ & $0.3^{\mathrm{c}}$ & Ryegrass & $309 \mathrm{~d}$ & $0.05 \mathrm{~m}^{2} \operatorname{pot}^{-1}$ & NR & $1.5-1.6^{\mathrm{c}}$ & [28] \\
\hline $\begin{array}{l}\text { Maize silage/wheat silage/dairy } \\
\text { manure/swine manure/other }\end{array}$ & $0.3^{\mathrm{c}}$ & Ryegrass & $309 \mathrm{~d}$ & $0.05 \mathrm{~m}^{2}$ pot $^{-1}$ & NR & $1.5-1.6^{\mathrm{c}}$ & [28] \\
\hline Maize silage/cattle manure/other & $0.3^{\mathrm{c}}$ & Ryegrass & $309 \mathrm{~d}$ & $0.05 \mathrm{~m}^{2}$ pot $^{-1}$ & NR & $1.5-1.6^{\mathrm{c}}$ & [28] \\
\hline Maize silage/wheat silage/other & $0.3^{\mathrm{c}}$ & Ryegrass & $309 \mathrm{~d}$ & $0.05 \mathrm{~m}^{2}$ pot $^{-1}$ & NR & $1.2-1.6^{\mathrm{c}}$ & {$[28]$} \\
\hline $\begin{array}{l}\text { Maize silage/clover, ryegrass } \\
\text { silage/other }\end{array}$ & $0.3^{\mathrm{c}}$ & Ryegrass & $309 \mathrm{~d}$ & $0.05 \mathrm{~m}^{2}$ pot $^{-1}$ & NR & $1.4-1.6^{\mathrm{c}}$ & [28] \\
\hline Maize silage/wheat silage/other & $0.3^{\mathrm{c}}$ & Ryegrass & $309 \mathrm{~d}$ & $0.05 \mathrm{~m}^{2} \mathrm{pot}^{-1}$ & NR & $1.5-1.6^{\mathrm{c}}$ & [28] \\
\hline Cattle manure/swine manure & $2.56^{\mathrm{c}}$ & Tomato & $5 \mathrm{mo}$ & $12 \mathrm{~m}^{2}$ & $121^{\mathrm{d}}$ & NR & [44] \\
\hline NR & 190 & Herbs/grasses/legumes & $4 \mathrm{mo}$ & $20 \mathrm{~m}^{2}$ & $4-4.5^{\mathrm{e}} \mathrm{kg}$ & NR & [43] \\
\hline Swine manure & $146-152$ & Silage Corn & $3 \mathrm{yr}$ & $21 \mathrm{~m}^{2}$ & $7-13 \mathrm{tha}^{-1}$ & 54-99 & {$[31]$} \\
\hline Swine manure & 100 & Grain corn & $3 \mathrm{yr}$ & $36 \mathrm{~m}^{2}$ & $6-11 \mathrm{tha}^{-1}$ & $83-176$ & [51] \\
\hline Cattle manure & $0-308$ & $\begin{array}{c}\text { Clover/winter } \\
\text { wheat/potatoes/maize/rye/peas/sp } \\
\text { elt/spring wheat/grass }\end{array}$ & $3 \mathrm{yr}$ & $72 \mathrm{~m}^{2}$ & $118 \mathrm{tha}^{-1}$ & 194 & [50] \\
\hline Household waste/food residues & 100 & Oats/barley & $4 \mathrm{yr}$ & $90 \mathrm{~m}^{2}$ & $2-4 \mathrm{t} \mathrm{ha}^{-1}$ & $39-77$ & [46] \\
\hline Swine manure/maize silage & $0-450$ & Clover grass/Perennial Ryegrass & $2 \mathrm{yr}$ & $144 \mathrm{~m}^{2}$ & $11.6 \mathrm{t} \mathrm{ha}^{-1}$ & 342 & [45] \\
\hline Swine manure & $76-172$ & Grain corn & $3 \mathrm{yr}$ & $835 \mathrm{~m}^{2}$ & $4-12 \mathrm{tha}^{-1}$ & $100-250$ & [49] \\
\hline Animal manure & $130-150$ & Energy maize & $2 \mathrm{yr}$ & 0.8 ha & NR & NR & [52] \\
\hline
\end{tabular}

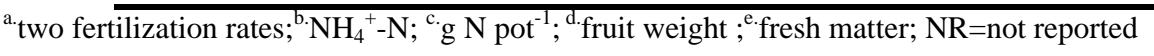




\subsection{Concerns with land application}

As mentioned previously, heavy metals are not a significant concern in AD effluent produced from agricultural and food wastes. However, several pathogenic organisms, including Salmonella, E. coli, and Clostridia, may be present in these AD feedstocks [41]. The inactivation of pathogens in AD is dependent on the initial amount of pathogens in feedstocks, digestion parameters (temperature, time), and nutrient contents [41]. Temperature is the most important factor affecting survival of pathogens in AD [41]. Most AD facilities operate under mesophilic conditions $\left(37^{\circ} \mathrm{C}\right)$, due to better process control and lower heating requirements [42]. However, pathogens survive more readily during mesophilic digestion [41].

The pathogens in mesophilic AD effluent may be a significant bottleneck to widespread acceptance of land application of $\mathrm{AD}$ effluent. For example, $\mathrm{AD}$ effluent with high pathogen levels could cause public health concerns, potentially reducing the land area available for agronomic application [41]. Food safety has become a hallmark of U.S. regulations, which may influence farmer perception of using organic fertilizers for crops for human consumption. Consequently, many large concentrated animal feeding operations (CAFOs) with AD operations may have limited outlets for AD effluent disposal [53]. Pathogens can be reduced through thermophilic $\mathrm{AD}\left(55^{\circ} \mathrm{C}\right)$ or other conditioning methods, including composting, heat drying, heat treatment, beta-ray or gamma-ray irradiation, and pasteurization [11]. However, many of these methods are costly, which has made lagoon storage an economical alternative to increase available storage to allow more flexibility in the timing of land application [54].

Out of these methods, composting has become a popular treatment method for $\mathrm{AD}$ effluent produced from agricultural and food wastes. This is primarily because of the operational simplicity and low costs associated with composting (Section 5.1). However, the high moisture content of AD effluent often requires addition of bulking materials, such as sawdust.

Irresponsible management of AD effluent nutrients also poses significant concerns. Traditional surface application methods, such as spray irrigation can cause volatile emissions (e.g. $\mathrm{NH}_{3}$ ). This is especially true for the liquid fraction of $\mathrm{AD}$ effluent after dewatering (Section 3.2), which contains higher 
proportions of the volatile TAN [5]. Depending on the soil microbial activity, nitrification and

2 denitrification of $\mathrm{NH}_{4}^{+}$to nitrous oxide $\left(\mathrm{N}_{2} \mathrm{O}\right)$ can cause negative impacts on local air quality [55]. Over-

3 supply of AD effluent can cause nutrient runoff [25]. For example, the nitrogen to phosphorus (N/P) ratio

4 in $\mathrm{AD}$ effluent is relatively stable. Application of $\mathrm{AD}$ effluent with low a N/P ratio for production of

5 crops that require a high N/P ratio may cause over-application of phosphorus, increasing the probability

6 of runoff and eutrophication in nearby waters. Additionally, the stable N/P ratio limits the ability to

7 control nutrient composition during farming, which may reduce farmer acceptance. Furthermore,

8 concerns over $\mathrm{NO}_{3}{ }^{-}$emissions to surface water and groundwater may lead to regulations that limit the

9 quantity of $\mathrm{AD}$ effluent allowed to be land applied [5]. Finally, long transportation distances reduce the

10 economic viability of AD effluent for land application [56]. Without close proximity to agricultural fields,

11 it may be more cost effective to use incineration, landfilling, composting or lagoons.

The issues of ammonia volatilization and nutrient runoff can be resolved using direct injection methods for reduced air-AD effluent contact [57] and springtime land application to exploit higher

14 nitrogen uptake rates by plants [11]. Advanced nutrient recovery techniques, such as struvite crystallization (Section 4.3.4), may be used to control nutrient composition in AD effluent. However, the diversity of environmental and economic concerns has prompted significant debate about the

17 sustainability of land application of AD effluent, which has been thoroughly discussed in previously

18 published reviews [5,38]. Additionally, there are limited long term studies on the effects of land

19 application on nutrient runoff, volatile emissions, pathogens, and economics [5]. The adoption of

20 dewatering practices (Section 3.2) has necessitated agronomic studies on using the liquid or solid fraction

21 of AD effluent as fertilizers. These issues have prompted development of emerging technologies to reuse,

22 remove, and recover components of $\mathrm{AD}$ effluent.

\section{3. Emerging techniques for treatment and reuse of raw AD effluent}

One of the main advantages of land application is that AD effluent can be recycled directly after 
2 effluent after dewatering (Section 4, Section 5).

$3 \quad$ 3.1 Reuse as AD inoculum

4

$\mathrm{AD}$ effluent is rich in active anaerobic microbes and nutrients, and can be re-used as AD inoculum. If high solids feedstocks, such as lignocellulosic biomass, are used for digestion, raw AD effluent can provide water to obtain an optimal DM content (20-25\%) for solid state anaerobic digestion (SS-AD). AD effluent can be used as inoculum directly through recirculation to AD reactors, or indirectly by mixing with feedstocks.. The inoculation procedure is different for L-AD and SS-AD reactors. To apply $\mathrm{AD}$ effluent as L-AD inoculum, effluent and feedstock are usually mixed and agitated inside the digester. This is often conducted by partial re-circulation. To use AD effluent as inoculum for SS-AD, effluent and feedstock need to be premixed outside of the digester, due to reduced ability to agitate mixtures with high solids contents. Partial premixing can be used to reduce energy demands, and has achieved similar methane yields compared to complete premixing [58]. Other methods, such as injection of inoculum into SS-AD reactors, may reduce inoculation size and energy costs. Produced biogas can be converted to heat using a combined heat and power (CHP) unit to maintain the temperature of both L-AD and SS-AD reactors [58]. The digestate from SS-AD has a higher DM content compared to L-AD effluent and can be land applied or composted.

L-AD effluent is more favorable than other sources of inocula (activated sludge, manure, rumen fluid), because it contains large populations of active methanogens and sufficient and available nutrients, and most importantly, it has been acclimated to the AD environment. There are a few studies that have compared the performance of different inocula sources for the production of methane by AD (Table 3). The available literature showed that $\mathrm{AD}$ effluent can initiate and produce relatively higher methane yields than alternative sources at both mesophilic and thermophilic temperatures. In one study, six inoculum types were employed for thermophilic SS-AD of the organic fraction of municipal solid wastes (OFMSW) [59]. Results showed that AD effluent had the highest methane yield of $530 \mathrm{~L} / \mathrm{kg}$-VS and the 
1 shortest AD lag phase. Performance of effluent recirculation was also tested, and a $16 \%$ increase in the

2 methane yield was achieved when effluent was recirculated, compared to water-feedstock dilution (1:1

3 dilution ratio) [60]. A recent study utilized autoclaved effluent to evaluate effects of microbial and non-

4 microbial factors on inoculum performance [61]. The results showed that non-microbial factors, such as

5 alkalinity, were most influential on methane yield for SS-AD at feedstock to effluent (F/E, VS/VS (g/g))

6 ratios of 2.2-6.6.

Table 3: Comparison of different inocula for anaerobic digestion

\begin{tabular}{|c|c|c|c|c|c|c|}
\hline Feedstock & $\operatorname{TS}(\%)$ & $\begin{array}{c}\text { Temperature } \\
\left({ }^{\circ} \mathrm{C}\right)\end{array}$ & Inoculum sources & $\begin{array}{c}\mathrm{CH}_{4} \text { yield } \\
\left(\mathrm{L} \mathrm{kg}^{-1}-\mathrm{VS}\right)\end{array}$ & $\begin{array}{l}\text { Lag phase } \\
\text { (\# of days) }\end{array}$ & Ref. \\
\hline \multirow{6}{*}{ Rice straw } & \multirow{6}{*}{-} & \multirow{6}{*}{37} & paper mill sludge & 10 & - & \multirow{6}{*}{ [62] } \\
\hline & & & digested municipal sludge & 15 & - & \\
\hline & & & digested chicken manure & 65 & 8 & \\
\hline & & & anaerobic granular sludge & 110 & 10 & \\
\hline & & & digested swine manure & 150 & 10 & \\
\hline & & & digested dairy manure & 175 & 7 & \\
\hline \multirow{4}{*}{ Animal byproducts } & \multirow{4}{*}{2.0} & \multirow{4}{*}{35} & UASB effluent & 195 & 21 & \multirow{4}{*}[63]{} \\
\hline & & & wastewater sludge & 317 & 10 & \\
\hline & & & anaerobic lagoon sludge & 1000 & 31 & \\
\hline & & & landfill leachate & 1059 & 20 & \\
\hline \multirow{3}{*}{ Corn stover } & \multirow{3}{*}{22} & \multirow{3}{*}{37} & municipal sewage sludge $\mathrm{AD}$ effluent & 120 & 2 & \multirow{3}{*}{ [64] } \\
\hline & & & food waste $\mathrm{AD}$ effluent & 195 & 2 & \\
\hline & & & dairy waste $\mathrm{AD}$ effluent & 238.5 & 2 & \\
\hline \multirow{6}{*}{ OFMSW } & \multirow{6}{*}{30} & \multirow{6}{*}{55} & cattle excrement & 30 & $2-4$ & \multirow{6}{*}[59]{} \\
\hline & & & corn silage & 110 & $2-4$ & \\
\hline & & & swine excrement & 180 & $2-4$ & \\
\hline & & & restaurant waste digested with rice hulls & 220 & $2-4$ & \\
\hline & & & swine mixed with digested sludge & 270 & $2-4$ & \\
\hline & & & digested sludge & 530 & $2-4$ & \\
\hline
\end{tabular}

8
9
One possible concern of recirculating $\mathrm{AD}$ effluent is the accumulation of TAN, volatile fatty acids (VFAs), and other metabolic products that may inhibit microbial activities. Therefore, AD effluent recirculation needs to be coupled with fresh water dilution or pretreated to control inhibitors. For instance, Nordberg et al. [65] reported that effluent recirculation resulted in increased $\mathrm{pH}$ and alkalinity during AD of alfalfa silage, which made it possible to increase the organic loading rate, but eventually caused 
inhibition. However, the AD performance was improved when 50\% of the recirculated liquid was

2 replaced by fresh water. Another concern about using AD effluent as SS-AD inoculum is the

3 transportation cost. Therefore, collocation of L-AD and SS-AD systems provides a solution to this issue

4 [66]. Although reuse of AD effluent as SS-AD inoculum is beneficial for enhanced biogas production, the

5 total volume and composition of the AD effluent does not decrease. Further management of the digestate

6 from SS-AD is required to alleviate mass accumulation.

$7 \quad 3.2$ Dewatering

Many of the emerging technologies require either the liquid or solid fraction of AD effluent. The

most common method to separate AD effluent components is dewatering, which has been shown to reduce $\mathrm{AD}$ effluent volume and improve solids handling [67].

Conventional methods for dewatering include centrifugation, screw press, and belt-filter press neutralization or molecular intercrossing [68]. Dewatering can provide an easier to handle solid fraction with much lower volume, and a liquid fraction mainly containing soluble nutrients [57]. After dewatering, the solid fraction of $\mathrm{AD}$ effluent contains concentrated levels of organic nitrogen and phosphorus, while the liquid fraction has more plant available TAN $[5,57]$. This indicates that the solid fraction of AD effluent could be used as a slow release fertilizer, while the liquid fraction is more applicable for rapid nutrient supply during irrigation [5]. Prior to land application, AD effluent should be stored to reduce volatile methane and ammonia emissions [57]. Environmentally friendly land application techniques, such as trailing hose, trailing shoe, and direct injection should be used to mitigate TAN emissions and uneven nutrient distribution [57]. Although spray irrigation is a lower cost option for the liquid fraction, this method has a greater risk of TAN volatilization and may cause uneven nutrient distribution [57].

Feedstock variability influences water distribution within AD effluent, which affects the efficiency of dewatering methodologies. Water is distributed as free water (not attached to particles), interstitial water (water trapped within flocs), surface water (water held on the surface of solid particles), and bound water (intracellular water) [68]. For AD effluent with more interstitial water, dewatering 
efficiency will likely be reduced. In fact, Lukehurst et al. [57] presented that conventional dewatering

2 produced lower and more variable DM capture efficiency for anaerobically digested manure (13-68\%)

3 than the reported capture efficiencies for anaerobically digested sewage sludge (50-80\%) [11]. This

4 indicates that AD effluents may have compositional variability that reduces dewatering efficiency.

5 Emerging dewatering methods include passive filtration, dissolved air flotation (DAF) and evaporation.

6 For example, Xia et al. (2012) showed that a pebble filter could be used to remove 81-98\% of TS from

7 anaerobically digested dairy manure, producing a low solids filtrate $(<2 \%$ TS $)$. DAF is commonly used by

8 treatment plants to concentrate anaerobically digested sewage sludge [11]. DAF has also been used to

9 further reduce solids from $\mathrm{AD}$ effluent prior to membrane filtration (Section 4.3.3). Fuchs and Drosg

10 (2013) indicated that $50 \%$ of the volume of the liquid fraction can be reduced by evaporation, which can

11 lower transportation costs. Although these techniques are effective, filtration requires long residence

12 times (>14 days), DAF requires high pressures (several atm), and evaporation requires high thermal energy demand (300-350 kWh/ton water removed)[69, 70]. Pilot scale studies are needed to compare the economic feasibility of emerging and conventional dewatering methods. Future work should also determine how $\mathrm{AD}$ operating parameters affect the water distribution within $\mathrm{AD}$ effluent, and use pilot scale studies to optimize dewatering processes. These studies are important because many emerging

17 methods require the liquid fraction of AD effluent to have very low solids content.

\section{Emerging techniques for management of the liquid fraction of AD effluent}

The liquid fraction is $90-95 \%$ of the total mass of commercial AD effluents [25, 28, 30].

Therefore, the majority of emerging techniques are designed to handle the liquid fraction of AD effluent.

21 After dewatering, the liquid fraction contains relatively low solids, significant amount of organics,

22 nitrogen, and phosphorus. Most commonly, the water and nutrients in the liquid fraction are reused for

23 irrigation and fertilizer [57]. However, there is debate about the environmental sustainability of spray

24 irrigation of $\mathrm{AD}$ effluent (Section 2.3). To improve treatment of the liquid fraction of AD effluent,

25 technologies have developed in recent years focusing on organics removal, water reuse, nutrient removal, 26 recovery, and reuse. 


\subsection{Microbial Fuel Cells for organics removal}

Microbial Fuel Cells (MFCs) are bioelectrochemical systems that convert organic material into electricity through exploitation of microbial metabolism [71]. MFCs consist of an anaerobic anode and aerobic cathode separated by an ion-selective membrane. In the anaerobic chamber, microbes oxidize organic matter, producing electrons and protons. Electrons are transferred through an external circuit, which can be used directly for electricity. The protons pass through the ion selective membrane, combining with oxygen $\left(\mathrm{O}_{2}\right)$ at the cathode to form water [71]. The most common method to treat organics in wastewater is the activated sludge process, where aerobic bacteria convert BOD/COD into microbial biomass and carbon dioxide [11]. While the activated sludge process is extremely effective and robust, it is energy intensive and produces large quantities of sludge [11]. Contrarily, MFCs produce little sludge, and also produce renewable electricity.

However, the success of MFCs may be limited by the biodegradability of organic matter within the AD effluent [71]. Because AD already stabilizes organic matter, there may be limited amounts of soluble organics available for MFCs. Although the liquid fraction of piggery waste AD effluent had COD levels as high as $4.1 \mathrm{~g} \mathrm{COD} \mathrm{L}^{-1}$ [72], it may not have enough readily biodegradable COD for successful organics removal and electricity production. For example, Ge et al. [73] showed that MFCs had a wide range of COD removal $(36.2 \pm 24.4 \%)$ and volatile suspended solids reduction $(46.1 \pm 19.2 \%)$ from digested sewage sludge, with a maximum produced power density of $3.2 \mathrm{~W} \mathrm{~m}^{-3}$ [73]. Contrarily, Inglesby and Fisher [74] achieved a much higher COD removal efficiency (63\%) and a columbic efficiency of 5.2\% when MFCs were loaded with effluent from the AD of Arthrospira maxima, a cyanobacteria. The success of this MFC was attributed to the presence of soluble organics, such as VFAs, which were not previously converted into methane during the $\mathrm{AD}$ process [74]. Based on the above studies, the composition of readily biodegradable organics affects the efficiency of MFCs for organics removal and electricity production. Furthermore, MFCs produce very little power, and scale up is difficult [71]. Therefore, future research should continue to evaluate MFCs for AD effluent treatment using scaled up modular 
arrangements. Another method for organics removal is the membrane bioreactor (MBR). MBRs offer the

2 advantage of filtering the biomass produced by the activated sludge process in one reactor, producing an

3 effluent with better water quality [75]. The downside to this method is that membranes are easily fouled

4 by suspended solids. However, development of MBRs for AD effluent treatment has been limited.

5 Therefore, economic and life cycle analyses that compare MFCs, activated sludge technology, and MBRs

6 are warranted.

$7 \quad 4.2$ Freshwater recycle

Freshwater is a limited resource that should be reused wherever possible. The liquid fraction of

9 AD effluent could be used for irrigation in areas of drought, for animal drinking water, and as a form of

10 process water in several industries. For example, AD has been frequently used as a low cost method to

11 treat distillage wastes from bioethanol plants. Moreover, due to high moisture content, the liquid fraction

12 of AD effluent could be recycled as the water source for ethanol fermentation. Zhang et al. [17]

13 developed an integrated ethanol fermentation and biogas production process in which distillage wastes

14 from the cassava-to-ethanol process were subjected to $\mathrm{AD}$, and the liquid fraction of $\mathrm{AD}$ effluent was

15 reused as a water source for the ethanol fermentation process. The advantage of this technique is that

16 water consumption during bioethanol production could be reduced. However, it would require removal of

17 inhibitors, including organic acids, sulfide, and ammonia, that can accumulate in AD effluent and could

18 inhibit ethanol fermentation [17, 76, 77]. For example, when Zhang et al. [17] applied untreated AD

19 effluent as the water source for fermentation, ethanol yield was $0.4 \%(\mathrm{v} / \mathrm{v})$ due to the presence of acetic

20 acid $\left(0.84 \mathrm{~g} \mathrm{~L}^{-1}\right)$ and propionic acid $\left(3.29 \mathrm{~g} \mathrm{~L}^{-1}\right)$. When organic acids were extracted from AD effluent,

21 ethanol yield was $10.1 \%(\mathrm{v} / \mathrm{v})$, similar to ethanol fermentation using tap water (10.3\%) [17]. One strategy

22 to reduce inhibitors is to use two digesters in series for enhanced removal of organic acids prior to

23 recycling the liquid fraction of AD effluent [17]. Another issue in reusing AD effluent for ethanol

24 production is that additional acid is required to decrease the $\mathrm{pH}$ from 8.0 to about 6.0. In order to address

25 the issue, Wang et al. [78] proposed mixing the $\mathrm{AD}$ effluent with a portion of the stillage, which has a pH

26 of around 4.2-4.6. Interestingly, Gao and $\mathrm{Li}$ [79] reported no inhibition while using the liquid fraction of 
1 thermophilic AD effluent for ethanol production. Additionally, when Gao and Li [79] used AD effluent as

2 a water source, ethanol concentration was $79.6 \mathrm{~g} \mathrm{~L}^{-1}$, an $18 \%$ increase compared to that using freshwater.

3 Moreover, similar integrated processes were reported for citric acid [80] or polyhydroxyalkanoates

4 (PHAs) production [81].

5 One major issue not mentioned in the previous research is that sterilization of AD effluent is

6 required to eliminate bacterial contamination prior to ethanol fermentation. This would significantly

7 increase energy requirements and operational costs for an integrated AD-ethanol biorefinery. So far, all

8 fermentation studies using $\mathrm{AD}$ effluent have been conducted at laboratory scale. Future studies should be

9 conducted at large scale, and should assess economical methods for AD effluent sterilization.

10 Furthermore, economic feasibility analyses should be conducted, especially at large scale.

$11 \quad$ 4.3 Nutrient removal, recovery, and reuse

12 4.3.1 ANAMMOX

13 Nitrogen and phosphorus discharged to waterways may lead to fish toxicity, eutrophication, and

14 hypoxia [82]. Therefore, nutrient removal is critical for effective AD effluent management. Anaerobic

15 ammonium oxidation (ANAMMOX) is an engineered process that exploits slow growing microorganisms

16 that convert ammonium $\left(\mathrm{NH}_{4}{ }^{+}\right)$directly to nitrogen gas $\left(\mathrm{N}_{2}\right)$ using nitrite $\left(\mathrm{NO}_{2}{ }^{-}\right)$as an electron acceptor

17 and inorganic carbon as an electron donor [83]. The process does not require an external organic carbon

18 source, drastically reducing costs compared to traditional nitrification and denitrification methods [84]. A

19 typical engineered system is designed to first partially oxidize $\mathrm{NH}_{4}{ }^{+}$into $\mathrm{NO}_{2}{ }^{-}$in a partial nitritation

20 reactor (PNR) prior to exposure to ANAMMOX bacteria [85] (Figure 2). 
Figure 2: Schematic of PNR-ANAMMOX for nitrogen removal from liquid fraction of AD effluent In Figure 2, the liquid fraction of $\mathrm{AD}$ effluent is diluted into a PNR such that the $\mathrm{NO}_{2}{ }^{-}$ concentration is suitable for ANAMMOX reactors. AD effluent can be introduced into ANAMMOX reactors to adjust the $\mathrm{NH}_{4}{ }^{+} / \mathrm{NO}_{2}{ }^{-}$ratio directly. Finally, recirculation could be used to maintain optimal hydraulic retention times (HRTs). Several design strategies are employed for PNR-ANAMMOX, including the continuously stirred tank reactor (CSTR), membrane bioreactor (MBR), sequencing batch reactor (SBR), immobilized bioreactor, single reactor system for high ammonia removal over nitrite (SHARON), and simultaneous nitritation and ANAMMOX in vertical flow recirculating biofilters [85, 86].

Magrí et al. [85] provided a thorough review of the primary factors affecting the efficiency of ANAMMOX treatment of AD effluent from manure digesters. To summarize, $\mathrm{NO}_{2}{ }^{-}, \mathrm{NH}_{4}+/ \mathrm{NH}_{3}$, inorganic carbon, organic carbon, $\mathrm{pH}$, temperature, and dissolved oxygen are the most important parameters that affect process efficiency (Table 4). AD effluent contains high levels of inhibitors such as TAN, and dilution or long HRTs may be required to sustain microbial cultures within the two-stage PNRANAMMOX process [85]. However, ANAMMOX microbes may be less sensitive than microbes in traditional nitrification and denitrification processes. For example, Obaja et al. [82] reported a toxic limit of $500 \mathrm{mg} \mathrm{L}^{-1} \mathrm{NH}_{4}{ }^{+}-\mathrm{N}$ for nitrifying and denitrifying bacteria. Still, the ANAMMOX process requires low levels of organic carbon (Table 4). Therefore, removal of organics from the liquid fraction of AD effluent 
may be required prior to PNR-ANAMMOX treatment [85]. Pilot scale PNR-ANAMMOX systems have

2 removed high levels of nitrogen $\left(500 \mathrm{~g}\right.$ nitrogen $\left.\mathrm{m}^{-3} \mathrm{~d}^{-1}\right)$ from the liquid fraction of AD effluent [87].

Table 4: Limits for effective nitrogen removal by ANAMMOX (adapted from Magrí et al. [85])

\begin{tabular}{cc}
\hline Parameter & Concentration range $\left(\mathbf{g ~ m}^{-3}\right)$ \\
\hline Ammonium $\left(\mathrm{NH}_{4}{ }^{+}\right)$ & $600-5900^{\mathrm{c}, \mathrm{e}}$ \\
Ammonia $\left(\mathrm{NH}_{3}\right)$ & $2-150^{\mathrm{a}, \mathrm{c}}$ \\
Nitrite $\left(\mathrm{NO}_{2}^{-}\right)$ & $100-182^{\mathrm{a}}$ \\
Inorganic carbon & $150-295$ \\
Organic carbon & $142-242^{\mathrm{a}}$ \\
Dissolved oxygen $(\mathrm{DO})$ & $1 \%^{\mathrm{f}}$ \\
$\mathrm{pH}$ & $6.5-8.8^{\mathrm{b}}$ \\
Temperature & $35-40^{\circ} \mathrm{C}^{\mathrm{d}}$ \\
Phosphate $\left(\mathrm{PO}_{4}\right)$ & $31-620$ \\
Sulfide $\left(\mathrm{S}^{2-}\right)$ & $1-64$ \\
Salinity & $8800-30000$ \\
\hline
\end{tabular}

a.reported levels of inhibitory concentration; ${ }^{\mathrm{b}}$ optimal at $8.0 ;{ }^{\mathrm{c}} \cdot{ }^{\text {dependent on } \mathrm{pH}} \mathrm{H} ;{ }^{\mathrm{d}}$. minimum temperature at $6{ }^{\circ} \mathrm{C}$;

e. loading rate in partial nitritation reactor (PNR); f.from Strous et al. [88]

Magrí et al. [85] assessed the feasibility of large scale PNR-ANAMMOX reactors for nitrogen removal from the liquid fraction of $\mathrm{AD}$ effluent from a manure digester. Their results indicated that the low organic $\mathrm{C} / \mathrm{N}$ ratio and significant $\mathrm{NH}_{4}{ }^{+}$content in the $\mathrm{AD}$ effluent made the process feasible. the process [85]. Despite these limitations, the PNR-ANAMMOX process had a lower specific energy requirement $\left(\mathrm{MJ} \mathrm{m}^{-3}\right)$ than air ammonia stripping/( $\left.\mathrm{NH}_{4}\right)_{2} \mathrm{SO}_{4}$ absorption (Section 4.3.2), traditional biological nitrogen removal, concentration by reverse osmosis (Section 4.3.3), struvite crystallization

14 (Section 4.3.4), steam ammonia stripping/ $\left(\mathrm{NH}_{4}\right)_{2} \mathrm{SO}_{4}$ absorption, and concentration by vacuum evaporation [85].

The compositional variation in AD effluent produced from different feedstocks (Table 1) will likely affect PNR-ANAMMOX effectiveness, and process optimization is necessary. If successful, application of PNR-ANAMMOX could provide harmless $\mathrm{N}_{2}$ gas and an effluent with little nitrogen, while using lower energy than traditional nitrification and denitrification. However, dilution is critical to mitigate inhibitory limits of $\mathrm{NH}_{3}$, phosphates, and sulfides (Table 4). The effects of microbial contamination on ANAMMOX effectiveness during AD effluent treatment has not been evaluated. Furthermore, ANAMMOX may lead to a net loss of reactive nitrogen, leading to increased demands for 
inorganic fertilizers. Life cycle analyses that evaluate the impacts of ANAMMOX treatment on the

2 nitrogen cycle are needed.

$3 \quad$ 4.3.2 Ammonia stripping

4

5

6

Biological methods for nitrogen removal are easily inhibited by compounds such as TAN, which is prevalent in $\mathrm{AD}$ effluent, and process kinetics can be severely inhibited by competing microorganisms. Also, biological processes do not recover the nitrogen in a usable form. Physiochemical methods can handle high levels of TAN, are not dependent on biological kinetics, and provide the added benefit of nitrogen recovery [89]. One of the most effective methods for physiochemical nitrogen removal and recovery is ammonia stripping and absorption.

Ammonia stripping is the phase change of $\mathrm{NH}_{3}$ from the liquid to the gas, which is achieved when a liquid containing $\mathrm{NH}_{3}$ comes in contact with air or steam that contains little or no $\mathrm{NH}_{3}$ [11]. The process is affected by the air/liquid ratio, pressure, $\mathrm{pH}$, and temperature, with improved efficiencies at high $\mathrm{pH}(10-11)$ and high temperature $\left(70^{\circ} \mathrm{C}\right)[15,89]$. The liquid fraction of $\mathrm{AD}$ effluent contains high levels of TAN and relatively high pH (7-8), making it ideal for ammonia stripping [15]. Ammonia stripping has recently been evaluated for AD effluent produced from food waste $[90,91]$ and agricultural manure [15]. In one study, Guštin and Marinšek-Logar [15] applied a continuous ammonia stripping process to the liquid fraction of digested pig slurry. High $\mathrm{pH}$ was critical to the performance, because it increased the $\mathrm{NH}_{3} / \mathrm{NH}_{4}{ }^{+}$ratio of the $\mathrm{AD}$ effluent prior to the stripping processes. Removal efficiencies were as high as $92.8 \%$ of TAN and $88.3 \%$ of TN, and the authors concluded that continuous ammonia stripping could substantially reduce the area of land required for agronomic land application of $\mathrm{AD}$ effluent [15]. In a separate study, De la Rubia et al. [90] applied ammonia stripping to AD effluent from source-separated food waste, using synthetic biogas $\left(65 \% \mathrm{CH}_{4}, 35 \% \mathrm{CO}_{2}\right)$ instead of air as the gas phase. TAN removal (13-44\%) was much lower than previous studies [15], likely because of low flow rates used during the process $\left(0.25\right.$ and $\left.0.375 \mathrm{~L}_{\text {biogas }} / \mathrm{L}_{\mathrm{AD} \text { effluent }} / \mathrm{min}\right)$.

The $\mathrm{NH}_{3}$ from the exiting gas phase can be converted to ammonium sulfate $\left(\left(\mathrm{NH}_{4}\right)_{2} \mathrm{SO}_{4}\right)$ through dilute sulfuric acid $\left(\mathrm{H}_{2} \mathrm{SO}_{4}\right)$ absorption [92]. In the absorption process, dilute $\mathrm{H}_{2} \mathrm{SO}_{4}$ reacts with $\mathrm{NH}_{3}$ 
laden air to form $\left(\mathrm{NH}_{4}\right)_{2} \mathrm{SO}_{4}$ that can be processed and sold as a nitrogen fertilizer. Packed bed acid

2 scrubbers use inert packing materials to provide surface for gas-liquid absorption. Packed bed scrubbers

3 are known for high $\mathrm{NH}_{3}$ removal efficiencies (>90\%) but exhibit high pressure drop. Acid spray scrubbers

4 have lower pressure drop but have slightly lower $\mathrm{NH}_{3}$ removal efficiency (71-81\%). These technologies

5 could be used for renewable $\left(\mathrm{NH}_{4}\right)_{2} \mathrm{SO}_{4}$ production from $\mathrm{NH}_{3}$ laden air after ammonia stripping of $\mathrm{AD}$

6 effluent [93].

7 Downsides to ammonia stripping include decreased efficiency at low temperatures, high costs of

8 heating, requirements for $\mathrm{pH}$ control and air/steam compression, foaming risk, and inability to remove

$9 \mathrm{NO}_{3}{ }^{-}$or $\mathrm{NO}_{2}{ }^{-}$[92]. Additionally, residual solids in $\mathrm{AD}$ effluent could induce clogging in ammonia

10 stripping towers [89]. Ammonia stripping is typically optimized to treat specific AD effluent, because AD

11 effluent composition can vary depending on AD operating conditions and feedstock components [89].

Electrochemical resource recovery has been used as a pretreatment step prior to ammonia

stripping/absorption of AD effluent [94]. Similar to an MFC, the electrochemical resource recovery

14 system had an anode and cathode separated by an ion exchange membrane, but voltage is applied to

15 induce current and ion exchange [94]. Desloover et al [94] applied high ionic strength on the cathode side

16 through addition of cations $\left(\mathrm{Na}^{+}, \mathrm{K}^{+}, \mathrm{Ca}^{2+}\right)$. Voltage addition caused net flux of the non- $\mathrm{NH}_{4}{ }^{+}$cations

17 from the cathode to anode, followed by increased flux of $\mathrm{NH}_{4}{ }^{+}$from the anode towards the cathode [94].

18 Using AD effluent, the authors demonstrated a nitrogen flux of $90 \mathrm{~g}$ nitrogen $\mathrm{m}^{-2} \mathrm{~d}^{-1}$ at a current density

19 application of $20 \mathrm{~A} \mathrm{~m}^{-2}$ [94]. After the $\mathrm{NH}_{4}{ }^{+}$flux to the cathode, alkaline conditions converted $\mathrm{NH}_{4}{ }^{+}$to

$20 \mathrm{NH}_{3}$ and an ammonia stripping/absorption system achieved 83\% removal efficiency [94]. Desloover et al

21 [94] indicated significant energy was required $\left(9 \mathrm{kWh} \mathrm{kg}^{-1}\right.$ nitrogen) for air stripping and $\left(\mathrm{NH}_{4}\right)_{2} \mathrm{SO}_{4}$

22 production after electrochemical concentration of TAN.

Ammonia stripping requires significant energy for heating/compression, and requires chemicals

24 for $\mathrm{pH}$ adjustment, making full-scale operation costly [92]. To reduce costs, process optimizations are

25 being conducted. For example, Jiang et al [89] conducted a pilot scale study for ammonia stripping the

26 liquid fraction of $\mathrm{AD}$ effluent from a dairy manure digester. They indicated that effective ammonia 
1 stripping (70-80\% removal rates) could be attained at low temperatures $\left(35^{\circ} \mathrm{C}\right)$, and lime requirements for

$2 \mathrm{pH}$ adjustment were not excessive [89]. Jiang et al [89] also stated that the process has the potential to

3 reduce the amount of land required for dairy manure application. However, these claims should be

4 validated at pilot scale at more $\mathrm{AD}$ facilities.

$5 \quad$ 4.3.3 Reverse osmosis

6

7

8

Another physiochemical method for nitrogen removal is reverse osmosis (RO). RO membranes are used to remove and recover ions from solution [67], including $\mathrm{NH}_{4}{ }^{+}$. $\mathrm{RO}$ systems have been utilized to retain $\mathrm{NH}_{4}{ }^{+}$from fertilizer manufacture effluents [95], landfill leachate [96], tannery wastewater [97], mine wastewater [98], and ammonia scrubber effluents [99] RO methods have also been applied for $\mathrm{NH}_{4}{ }^{+}$removal from AD effluent (Figure 3). For example, Bilstad et al. [100] used RO for nitrogen recovery from digested manure. The process removed $95 \%$ of input total nitrogen, which was retained in the liquid fraction (concentrate), and was therefore considered a viable liquid fertilizer [100]. Additionally RO is effective at high initial TAN concentrations, as demonstrated by Masse et al. [16] who achieved $>99 \% \mathrm{NH}_{4}{ }^{+}$retention efficiency using AD effluent with high initial TAN levels $\left(10,000 \mathrm{mg} \mathrm{L}^{-1}\right)$.



Figure 3: Reverse osmosis for removal of nitrogen from liquid fraction of $\mathrm{AD}$ effluent

The RO process is influenced by operating pressure, $\mathrm{pH}$, and temperature. Higher pressures promote higher flux of $\mathrm{AD}$ effluent through membranes [67], while low $\mathrm{pH}$ produces higher proportions of $\mathrm{NH}_{4}{ }^{+}$, which is retained in the concentrate [16]. However, AD effluent contains solids that can cause membrane fouling during RO [101]. Even after dewatering, the liquid fraction still contains suspended 
solids that may clog RO membranes [101]. Therefore, sieving or dissolved air flotation (DAF) followed

2 by membrane filtration (i.e. microfiltration, ultrafiltration) have been used to enhance RO efficiency [16,

3 70]. Also, acidification could be used to increase the $\mathrm{NH}_{4}{ }^{+} / \mathrm{NH}_{3}$ ratio (Figure 3) [16]. However, pre-

4 filtration and acidification may be costly, limiting the economic viability of RO. To combat fouling,

5 Vaneeckhaute et al. [101] applied vibratory shear enhanced processing (VSEP) for macronutrient removal

6 from the liquid fraction of AD effluent. Estimates showed that VSEP could reduce overall energy costs

7 and the concentrate fertilizer was estimated to have a value of $€ 6.3 \pm 1.1 \mathrm{t}^{-1}$ fresh weight (\$8.6) [101].

8 Another method to improve the cost effectiveness of RO uses purification of byproduct streams in the

9 concentrate. Aside from nitrogen, potassium and VFAs present in AD effluent are also retained by RO

10 membranes [16]. Potassium (K) is an important fertilizer for many crops (Section 2.2). Because they are

11 used in pharmaceutical, petrochemical, food, cosmetics, and tanning industries, retention of VFAs by RO

12 could become a valuable practice [102], improving the economic viability of AD systems[104].

\section{$13 \quad$ 4.3.4 Struvite crystallization}

14

Phosphorus is a valuable agricultural fertilizer. However, high purity phosphate mines are rapidly depleting [103]. These issues have prompted the reuse of AD effluent as an organic fertilizer for crop production (Table 2). However, land application of AD effluent with low N/P ratio may result in over application phosphorus and runoff (Section 2.3). To increase the N/P ratio, phosphorus could be removed and recovered by struvite crystallization. Struvite crystallization can help control the N/P ratio while simultaneously producing a slow release phosphate fertilizer [104].

Significant quantities of $\mathrm{NH}_{4}{ }^{+}$and some soluble phosphorus $\left(\mathrm{PO}_{4}{ }^{3-}, \mathrm{HPO}_{4}{ }^{2-}, \mathrm{H}_{2} \mathrm{PO}_{4}{ }^{-}, \mathrm{H}_{3} \mathrm{PO}_{4}\right)$ are in the liquid fraction of $\mathrm{AD}$ effluent. Controlled nucleation (crystal birth) and crystallization (crystal growth) of struvite $\left(\mathrm{MgNH}_{4} \mathrm{PO}_{4} \cdot 6 \mathrm{H}_{2} \mathrm{O}\right)$ occur under supersaturated conditions by the equimolar reaction below [105]:

$$
\mathrm{Mg}^{2+}+\mathrm{NH}_{4}^{+}+\mathrm{H}_{n} \mathrm{PO}_{4}^{n-3}+6 \mathrm{H}_{2} \mathrm{O} \rightarrow \mathrm{MgNH}_{4} \mathrm{PO}_{4} * 6 \mathrm{H}_{2} \mathrm{O}+n \mathrm{H}^{+}
$$


2 reviewed, and is affected by thermodynamic and mass transfer properties, $\mathrm{pH}$, supersaturation, mixing,

3 crystal size, impurities, and seed addition [12]. AD effluent does not have significant quantities of

4 dissolved magnesium (Table 1); therefore, external sources, including magnesium chloride $\left(\mathrm{MgCl}_{2}\right)$,

5 magnesium oxide $(\mathrm{MgO})$, and magnesium hydroxide $\left(\mathrm{Mg}(\mathrm{OH})_{2}\right)$, may be necessary to induce struvite

6 crystallization. One example of a struvite reactor is the fluidized bed design in Koch et al.[106]'s patented

7 process, adapted and outlined in Figure 4. Small struvite particles, formed at the top of the reactor, slowly

8 settled into sections of reducing diameter as they aggregated [107]. The settling zone is where largest

9 struvite crystals were harvested. Use of this technique produced high-purity (99.8\%) struvite crystals that

10 progressed from loosely aggregated to solidly bound pellets [107].

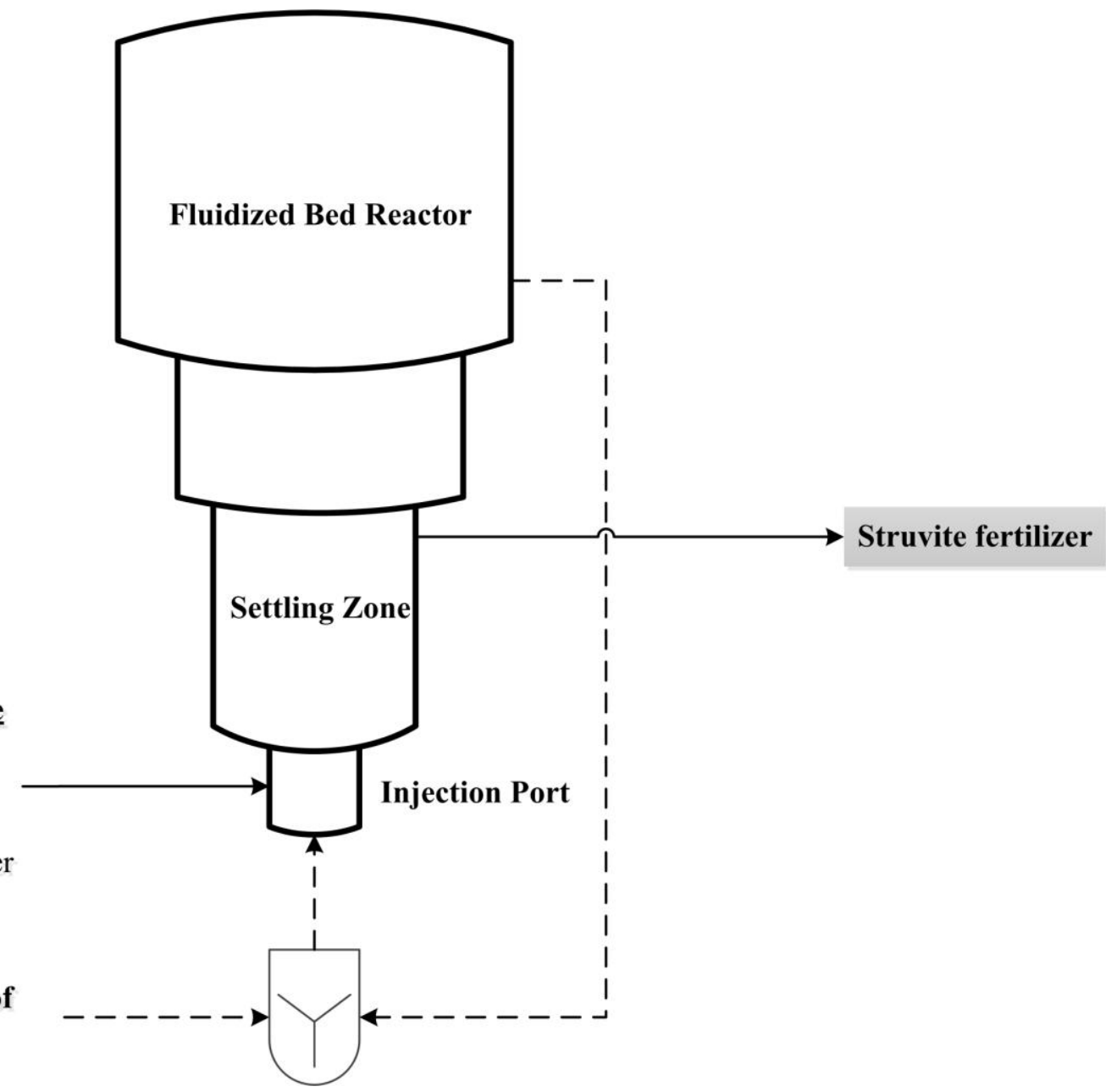

Figure 4: Staged fluidized bed reactor for struvite crystallization (adapted from Koch et al. [106]) 
Struvite crystallization of AD effluent from agricultural waste digesters has been difficult. This is

2 because the dissolved phosphate content in digested agricultural feedstocks may also be too low for

3 proper struvite crystallization. Therefore, external phosphate may be needed, which increases costs. In

4 fact, Zeng and $\mathrm{Li}[108]$ showed that the $\mathrm{Mg} / \mathrm{PO}_{4}{ }^{3-}$ ratio needed to be five times higher than the

5 stoichiometric requirements to induce struvite crystallization from digested cattle manure. AD effluent

6 also has high levels of calcium, especially when cow manure is the AD feedstock [109]. The calcium

7 competes with magnesium to form calcium phosphate precipitates, which may not be as valuable for

8 downstream processing, because they are amorphous rather than crystalline [109].

9 The issues associated with struvite production from agricultural AD effluents could potentially be overcome. Dissolved phosphorus content can be increased through chemical pretreatment. Yilmazel and Demirer [110] showed that acidification of the solid fraction of AD effluent produced a phosphorus enriched solution. Yilmazel and Demirer [110] attained nearly complete phosphorus (99.6\%-100\%) and partial $\mathrm{NH}_{4}-\mathrm{N}$ (3.3-65.6\%) recoveries from the phosphorus enriched solution in an optimized fluidizedbed reactor [110]. To release phosphorus from calcium phosphates in struvite reactors, Zhang et al. [111] added EDTA as a chelating agent. Their results showed that EDTA successfully released phosphorus, but warned that higher EDTA levels contributed to breakup of struvite [111].

Based on these studies, nutrients from the liquid fraction of AD effluent could be recovered by struvite crystallization. However, the high cost of magnesium inputs is difficult to overcome. For example, it has been estimated that struvite is more expensive than conventional rock phosphate because of the high magnesium cost [112]. To combat this issue, Lahav et al. [113] applied nanofiltration to

21 seawater and used the filtrate as the magnesium source for struvite crystallization. Struvite recovery

22 remained high $(>95 \%)$ despite the high content of calcium in most seawater salts [113]. A separate

23 recovery technique is hydroxyapatite $\left(\mathrm{Ca}_{10}\left(\mathrm{PO}_{4}\right)_{6}(\mathrm{OH})_{2}\right)$ crystallization, in which dissolved phosphorus

24 adsorbs to cheap seeding materials and crystallizes into hydroxyapatite [114]. The composition of

25 hydroxyapatite is similar to phosphate rocks, indicating it could be integrated into existing fertilizer

26 manufacturing [114]. The use of acidification as pretreatment [110] and low cost magnesium inputs [113] 
could improve the cost-effectiveness of struvite crystallization. Future investigations should evaluate

2 struvite crystallization from AD effluent at larger scale and conduct economic analyses for feasibility

3 assessment for both centralized and farm scale AD systems.

$4 \quad$ 4.3.5 Hydroponics

Irrigation of the liquid fraction of $\mathrm{AD}$ effluent is effective because it is simple and produces

7 valuable crops. However, environmental and economic concerns may limit this practice (Section 2.3).

8 Use of the liquid fraction of AD effluent for controlled cultivation of crops in hydroponic systems could

9 ameliorate issues related to soil quality, because plants are grown in nutrient solutions without soil.

10 Additionally, hydroponic systems are isolated, and unused nutrients are more easily controlled and can be

11 recycled for reuse. In one study, Liedl et al. [115] showed that hydroponic production of lettuce was

12 comparable using the liquid fraction of AD effluent from a poultry waste digester or commercial

13 fertilizers. However, some fruits were less amenable to $\mathrm{AD}$ effluent, due to the low $\mathrm{NO}_{3}{ }^{-}$content. Liedl et

14 al. [115] showed that the $\mathrm{NH}_{4}{ }^{+}$in $\mathrm{AD}$ effluent needed to be converted into $\mathrm{NO}_{3}{ }^{-}$for successful hydroponic

15 tomato production [115]. Furthermore, dilution of the liquid fraction of AD effluent may be required to

16 alleviate $\mathrm{NH}_{4}{ }^{+}$toxicity. Krishnasamy et al. [19] evaluated dilutions of $\mathrm{AD}$ effluent for the best growth of

17 silverbeet in a hydroponic system. They found $20 \% \mathrm{AD}$ effluent dilution mitigated $\mathrm{NH}_{4}{ }^{+}$toxicity and

18 provided the best conditions for silverbeet growth. However, silverbeet growth was higher in a

19 commercial hydroponic growth solution [19]. There are few studies on the hydroponic production of

20 plants using AD effluent as the nutrient solution. Additionally, these studies did not investigate the

21 impacts of microbial contamination during hydroponic production, which are crucial to ensure fruits and

22 vegetables are safe for human consumption (Section 2.3). Another option to integrate AD and

23 hydroponics is to utilize $\mathrm{CO}_{2}$ and waste heat produced during biogas combustion for hydroponic

24 greenhouse operation.

25 4.3.6 Algae production

Similar to hydroponic plant production, algae growth is strongly dependent on light exposure, 28 temperature, carbon dioxide $\left(\mathrm{CO}_{2}\right)$, and nutrients such as nitrogen and phosphorus. Unlike hydroponic 
1 plants, algae biomass contains high lipids [116], which have potential for conversion to biodiesel [117].

2 The liquid fraction of AD effluent contains high levels of nitrogen and phosphorus (1000-3000 mg L ${ }^{-1}$

$\left.3 \mathrm{TN}, 400-500 \mathrm{mg} \mathrm{L}^{-1} \mathrm{TP}[118,119]\right)$ that can be used to supply nutrients for growth of non-toxic, lipid-rich

4 algae biomass. However, the turbidity in $\mathrm{AD}$ effluent may cause inadequate light penetration for sustained

5 algae growth. For example, Wang et al. [120] demonstrated that the growth rate of Chlorella sp. in AD

6 effluent declined linearly with increasing initial reactor turbidity. Furthermore, Park et al. [121] showed

7 that Scenedesmus sp. was inhibited by $\mathrm{NH}_{3}$ at low levels $\left(100 \mathrm{mg} \mathrm{L}^{-1}\right)$. To reduce the effects of turbidity

8 and inhibitory $\mathrm{NH}_{3}$, most researchers have diluted the liquid fraction of $\mathrm{AD}$ effluent to initial TN levels of

9 less than $200 \mathrm{mg} \mathrm{L}^{-1}$ (Table 5). This practice also diluted turbidity for improved light penetration. While

10 the growth rate of algae can also be improved by optimizing the nitrogen to phosphorus (N/P) ratio [122],

11 low nutrient content promotes lipid production [118]. Therefore, studies have attempted to optimize the

12 nutrient loading to maintain growth and high lipid yields. Figure 5 displays a theoretical process for algae

13 production using the liquid fraction of $\mathrm{AD}$ effluent for nutrients, brackish water as the water source, and

$14 \mathrm{CO}_{2}$ supplemented from biogas combustion. This method could provide a cost effective method for $\mathrm{AD}$

15 effluent reuse. 




Figure 5: Algae production from waste products of the AD process Selected publications where AD effluent was used for algae nutrients are summarized in Table 5. The most highly studied strains for the use of AD effluent nutrients are the freshwater microalgae genera Chlorella and Scenedesmus. Strains of freshwater algae are known for high growth rates (0.3-1.7 $\left.\mathrm{d}^{-1}\right)$ and high nutrient removal (60-95\%) [123]. Some freshwater strains can also be used for biogas upgrading through $\mathrm{CO}_{2}$ assimilation [124]. Furthermore, Chlorella and Scenedesmus may also be mixotrophic, consuming $\mathrm{CO}_{2}$ via photoautotrophic metabolism while simultaneously consuming VFAs from AD effluent via heterotrophic metabolism $[125,126]$. Despite the advantages of using freshwater strains,

11 substantial freshwater requirements may limit process economics and sustainability [127]. To combat

12 these issues, marine strains could be cultivated in AD effluent diluted with seawater or brackish water.

13 Under an optimal dilution $(6 \% \mathrm{v} / \mathrm{v})$ of the liquid fraction of AD effluent in artificial seawater, biomass 14 productivity of Nannochloropsis salina was $92 \mathrm{mg}$ dry weight (DW) $\mathrm{L}^{-1} \mathrm{~d}^{-1}$ with nearly $30 \%$ lipids, higher 15 than most freshwater strains cultivated in $\mathrm{AD}$ effluent. When $\mathrm{AD}$ effluent was used for algae nutrients in 16 scaled up open channel raceway cultivation systems, growth rates were lower compared to laboratory 17 cultures. Reduced growth rates were attributed to restricted light penetration and culture instability caused 18 by predators [119, 128, 129]. 
Table 5: Algae biomass production using the liquid fraction of $\mathrm{AD}$ effluent as nutrient source

\begin{tabular}{|c|c|c|c|c|c|c|c|c|c|c|}
\hline \multirow[b]{2}{*}{ Algae strain } & \multirow[b]{2}{*}{$\begin{array}{l}\text { Working } \\
\text { Volume }(\mathbf{L})\end{array}$} & \multirow[b]{2}{*}{$\begin{array}{c}\mathrm{AD} \\
\text { feedstock }\end{array}$} & \multicolumn{2}{|c|}{$\mathrm{TN}$ in algae reactor } & \multicolumn{2}{|c|}{ TP in algae reactor } & \multicolumn{2}{|c|}{ Biomass Production } & \multirow[b]{2}{*}{$\begin{array}{l}\text { Lipid Content } \\
\text { (\% dry weight) }\end{array}$} & \multirow[b]{2}{*}{ Reference } \\
\hline & & & $\begin{array}{c}\text { Initial } \\
\text { Concentration } \\
\left(\mathrm{mg} \mathrm{L}^{-1}\right)\end{array}$ & Removal (\%) & $\begin{array}{c}\text { Initial } \\
\text { Concentration } \\
\left(\mathrm{mg} \mathrm{L}^{-1}\right)\end{array}$ & Removal (\%) & $\begin{array}{l}\text { Growth rate } \\
\qquad\left(\mathrm{d}^{-1}\right)\end{array}$ & $\begin{array}{c}\text { Biomass } \\
\text { Productivity } \\
\left(\mathrm{mg} \mathrm{DW} \mathrm{L}^{-1} \mathrm{~d}^{-1}\right)\end{array}$ & & \\
\hline $\begin{array}{l}\text { Chlorella sorokiana } \\
\text { Chlorella minutissima } \\
\text { Scenedesmus bijuga }\end{array}$ & $0.06-0.2$ & Poultry litter & $80-100^{\mathrm{a}}$ & $50-80^{\mathrm{a}}$ & $7-8^{\mathrm{a}}$ & $70-75^{\mathrm{a}}$ & NR & $71-75$ & $3.5-9.6$ & [130] \\
\hline Chlorella sp. & 0.1 & Dairy manure & $120-250^{\mathrm{a}, \mathrm{b}}$ & $76-83$ & $15-30^{\mathrm{a}, \mathrm{b}}$ & $63-75$ & $0.28-0.41$ & NR & $9.0-13.7^{\mathrm{c}}$ & [120] \\
\hline Scenedesmus sp. AMDD & 0.1 & $\begin{array}{l}\text { Vegetable, cow, } \\
\text { swine, algae } \\
\text { waste }\end{array}$ & $23-28^{\mathrm{a}}$ & $23-100$ & $8.5-22^{\mathrm{a}}$ & $13-99$ & $0.85-1.66$ & NR & NR & [131] \\
\hline Chlorella sp. UMN271 & 0.15 & Swine manure & $200-250^{\mathrm{a}}$ & $22-34$ & $10-55^{\mathrm{a}}$ & $23-71$ & $0.50-0.65^{\mathrm{a}}$ & $0.04-0.08^{\mathrm{a}}$ & $7.5-10.9^{c}$ & [125] \\
\hline Chlorella $s p \&$ bacteria & 0.5 & $\begin{array}{l}\text { Wastewater } \\
\text { sludge }\end{array}$ & $225^{\mathrm{a}}$ & $89^{\mathrm{a}}$ & $120^{\mathrm{a}}$ & $17^{\mathrm{a}}$ & NR & $30^{\mathrm{a}}$ & NR & [132] \\
\hline Scenedesmus sp. & 1 & Livestock waste & 120 & $40-55^{\mathrm{a}}$ & NR & NR & 0.04-0.09 & $46-57$ & NR & [121] \\
\hline Nannochloropsis salina & 1 & $\begin{array}{l}\text { Wastewater } \\
\text { sludge }\end{array}$ & $80-640$ & $87-100$ & $11.4-91.4$ & $98-100$ & $0.344-0.644$ & $68-92$ & $21-36$ & [118] \\
\hline Synechocystis sp. & 1 & $\begin{array}{l}\text { Wastewater } \\
\text { sludge }\end{array}$ & $80-640$ & $71.2-100$ & 11.4-91.4 & $99-100$ & NR & $41.3-150.9$ & $11.8-13.5$ & [133] \\
\hline $\begin{array}{l}\text { Chlorella sp. } \\
\text { Micractinium sp. }\end{array}$ & 2 & $\begin{array}{l}\text { Wastewater } \\
\text { sludge }\end{array}$ & 197 & $\begin{array}{l}51 \\
46\end{array}$ & 3.5 & $\begin{array}{l}95 \\
95\end{array}$ & $\begin{array}{l}0.13 \\
0.14\end{array}$ & $\begin{array}{l}66^{\mathrm{a}} \\
53^{\mathrm{a}}\end{array}$ & NR & [123] \\
\hline $\begin{array}{l}\text { Chlorophycae \& } \\
\text { cyanobacteria }\end{array}$ & 8 & $\begin{array}{l}\text { Wastewater } \\
\text { sludge }\end{array}$ & $45-80^{\mathrm{a}}$ & $48-92^{\mathrm{a}}$ & $5-11^{a}$ & $98^{\mathrm{a}}$ & NR & 234 & NR & [134] \\
\hline $\begin{array}{l}\text { Chlorella sp. } \\
\text { Chlorella sp. }\end{array}$ & $\begin{array}{c}12 \\
20^{\mathrm{d}}\end{array}$ & $\begin{array}{c}\text { NR } \\
\text { Dairy manure }\end{array}$ & $\begin{array}{c}481 \\
40-200^{\mathrm{e}}\end{array}$ & $\begin{array}{c}78 \\
72-98^{\mathrm{e}}\end{array}$ & $\begin{array}{c}51 \\
\text { NR }\end{array}$ & $\begin{array}{c}73 \\
55-58^{\text {e }}\end{array}$ & $\begin{array}{c}\mathrm{NR} \\
0.016^{\mathrm{d}}\end{array}$ & $\begin{array}{l}37-59 \\
22.8^{d}\end{array}$ & $\begin{array}{c}\mathrm{NR} \\
9.3-10.8^{\mathrm{e}}\end{array}$ & $\begin{array}{l}{[124]} \\
{[135]}\end{array}$ \\
\hline $\begin{array}{l}\text { Mixed green algae } \\
\text { culture }\end{array}$ & 40 & Dairy manure & $16.3-30.5$ & 96 & $1.8-2.6$ & 98 & NR & 17.5 & $10-29$ & [128] \\
\hline Spirulina platensis & 100 & Pig waste & 28.2 & $80^{\mathrm{a}}$ & 17.6 & $30^{\mathrm{a}}$ & $\mathrm{NR}$ & $19.9^{\mathrm{f}}$ & 4.2 & [136] \\
\hline
\end{tabular}

${ }^{\mathrm{a}}$ estimated from chart data; ${ }^{\mathrm{b}}$ Total Kjeldahl Nitrogen $(\mathrm{TKN}) ;{ }^{\mathrm{c}}$.Total fatty acids (TFA); ${ }^{\mathrm{d}}$ results from pilot-scale study; ${ }^{\mathrm{e}}$ results from laboratory-scale study; ${ }^{\mathrm{f}} \mathrm{g} \mathrm{m}^{-2} \mathrm{~d}^{-1}$ 
Use of nutrients from the liquid fraction of $\mathrm{AD}$ effluent for non-toxic algae growth has potential

2 to become an effective reuse option. However, several issues undermine the development of this

3 technology. First, AD effluent contains residual solids that limit light penetration [120] and levels of $\mathrm{NH}_{3}$

4 that may be inhibitory for algae growth [121]. Furthermore, introduction of predators from AD effluent

5 could inhibit the growth of algae, especially in open raceway ponds. However, few studies have applied

6 unsterilized AD effluent as a nutrient source for algae growth $[118,119]$. In both of those studies, $N$.

7 salina growth was not inhibited in lab scale cultures $[118,119]$. Some potential solutions to combat

8 predators are screening for algae strains that are robust to microbial contaminants, rapid

9 detection/tracking of predators, and filtration of $\mathrm{AD}$ effluent prior to use $[129,137]$. However, these

10 solutions may increase costs, limiting the incentive to use algae lipids for low value biodiesel.

11 Additionally, use of the whole algae biomass for biogas production via AD eliminates the expensive lipid

12 extraction step, lowering operational costs [138]. To further reduce operational costs and improve

13 sustainability, use of brackish or seawater is preferred. Compared to digested sewage sludge, AD effluent

14 from agricultural wastes has lower levels of pathogens and heavy metals, indicating the algae produced

15 could be used for more high value applications, such as animal feed.

\section{Emerging techniques for reuse of the solid fraction of AD effluent}

After dewatering, the solid fraction of AD effluent can be stabilized by traditional methods,

21 However, traditional handling methods may be costly and environmentally intensive [10]. In order to

22 improve management economics, several technologies are in development for effective treatment and

23 reuse of the solid fraction of $\mathrm{AD}$ effluent.

$24 \quad$ 5.1 Composting

Although composting is an older technology, it has emerged as a leading treatment technique for 27 the solid fraction of AD effluent. Due to high temperature and aerobic microbial activities, composting 
has the potential to remove pathogens and stabilize organic matter, thereby improving soil amendment

2 properties. Composting also reduces the volume of AD effluent, improving transport economics.

3 Composting requires a relatively low moisture content (40-75\%) compared to AD. To reach the desired

4 moisture content for successful composting, dewatering of $\mathrm{AD}$ effluent is normally required. For example,

5 Lin et al [140] had to centrifuge raw $\mathrm{AD}$ effluent to $30 \% \mathrm{DM}$ prior to mixing with yard trimmings in

6 order to reach the $35-55 \% \mathrm{DM}$ content required for composting. Some of the studies discussed in this

7 section have also employed raw AD effluent and a co-composting bulking agent to attain the desired

8 moisture contents. Thus, composting may offer an additional advantage for AD water reuse.

9 The success of composting is determined by several key factors, such as composition of

10 composting materials, temperature, aeration, water content, $\mathrm{pH}$, and turning. The $\mathrm{C} / \mathrm{N}$ ratio of digested

11 materials is recommended to be 20-30 for composting [141]. AD effluent usually contains a high nitrogen

12 concentration, supplied from the degradation of organic nitrogen (proteins, amino acids). AD effluent

13 should be co-composted with carbon rich and relatively dry bulking agents to balance the $\mathrm{C} / \mathrm{N}$ ratio and

14 moisture content. Previous studies have employed yard trimmings, vine shoot prunings, and sawdust as

15 the bulking agents. Additives such as almond shell powder may also be added (1\% fresh mass basis) to

16 further increase the $\mathrm{C} / \mathrm{N}$ ratio [13].

17 Aeration and composting temperature are also closely related. Sufficient air is necessary to

18 support microbial activity, which generates heat and destroys pathogens, while too much air may result in

19 temperature decrease [11].Currently, there are two strategies to control aeration and temperature for

20 composting AD effluent at small scale facilities. One strategy is to set a ceiling temperature and adjust

21 aeration to maintain that temperature. For example, Das [142] co-composted AD effluent and yard

22 trimmings and set a ceiling temperature of $55^{\circ} \mathrm{C}$. In that test, when the operating temperature was higher

23 than $55^{\circ} \mathrm{C}$, air was provided continuously at a rate of $730 \mathrm{~m}^{3}$ air $\mathrm{m}^{-3}$ reactor $\mathrm{d}^{-1}$. When the temperature

24 was lower than $55^{\circ} \mathrm{C}$, the compost was aerated intermittently (equivalent to $18 \mathrm{~m}^{3}$ air $\mathrm{m}^{-3}$ reactor $\mathrm{d}^{-1}$ ). An

25 alternative strategy is to control the aeration but not temperature. Franke-Whittle et al. [143] continuously

26 provided aeration at a rate of $24 \mathrm{~m}^{3}$ air $\mathrm{m}^{-3}$ reactor $\mathrm{d}^{-1}$, and the compost temperature achieved a high value 
$1 \quad\left(>70^{\circ} \mathrm{C}\right)$ within two days, followed by rapid decline to lower temperatures $\left(25-35^{\circ} \mathrm{C}\right)$. Despite the rapid

2 temperature decline, the authors indicated the final compost in the laboratory trial was hygienically

3 acceptable [143]. Turning is also used to provide oxygen and to homogenize composting materials [144].

For composting of $\mathrm{AD}$ effluent with bulking agents, the overall moisture content is normally

5 maintained above $40 \%$ to support microbial growth. The amount of AD effluent used depends on the

6 water holding capacity of the bulking agent and the mixing ratio of effluent and bulking agent.

7 Composting material $\mathrm{pH}$ is usually controlled to be above 7 but lower than 9 to promote favorable

8 microbial growth conditions. Additives such as nitric acid and elemental sulfur have been used to reduce

$9 \mathrm{pH}$ of mixtures $[13,142]$. Composting of AD effluent usually took 1-2 months and can be shorter than

10 the regular composting process, due to the abundance of microbial communities in the AD effluent. Table

116 summarizes the conditions for co-composting $\mathrm{AD}$ effluents and bulking agents.

Table 6: Summary of composting operating conditions

\begin{tabular}{|c|c|c|c|c|c|c|c|}
\hline Inputs for composting & $\begin{array}{c}\text { Ceiling } \\
\text { Temperatu } \\
\text { re }\left({ }^{\circ} \mathrm{C}\right)\end{array}$ & $\begin{array}{c}\text { Aeration, } \\
\left(\mathrm{m}^{3} \text { air } \mathrm{m}^{-3} \text { reactor }\right. \\
\left.\mathrm{d}^{-1}\right)\end{array}$ & $\begin{array}{c}\text { Moisture } \\
\text { (\%w.b.) }\end{array}$ & e Initial & $\begin{array}{l}\text { Operation } \\
\text { time } \\
\text { (day) }\end{array}$ & $\begin{array}{l}\text { Turning } \\
\text { times }\end{array}$ & Ref. \\
\hline $\begin{array}{l}\text { AD effluent of } 0.05-0.20 \mathrm{~L} / \mathrm{kg} \text {, Yard } \\
\text { trimming. Additive: } \mathrm{HNO}_{3}\end{array}$ & 55 & $\begin{array}{l}730 \text { at }>55^{\circ} \mathrm{C} \\
18 \text { at }<55^{\circ} \mathrm{C}\end{array}$ & 55.6 & $7.64-9.39$ & ) $43-44$ & 2 & {$[142]$} \\
\hline $\begin{array}{l}\text { Green wastes (52.4\%), AD effluent } \\
(26.2 \%) \text { and compost }(21.5 \%)\end{array}$ & - & 24 & 64 & 7.10 & 63 & 3 & {$[143]$} \\
\hline $\begin{array}{l}\text { Solid fraction of AD effluent ( } 80- \\
100 \%) \text { and vine shoot pruning }(0-20 \%) \text {. } \\
\text { Additive: elemental sulfur }(0.2 \%) \text { and } \\
\text { almond shell powder }(1 \%)\end{array}$ & 65 & $\begin{array}{l}\text { Adjustable based on } \\
\text { the temperature }\end{array}$ & $>40$ & $8.34-8.46$ & 95 & 2 & [13] \\
\hline $70 \%$ effluent and $30 \%$ yard trimmings & - & Forced aeration & 30.5 & 8.83 & 28 & daily & {$[145]$} \\
\hline Manure effluent and sawdust & 70.1 & Manual rotation & $>40$ & 8.19 & 56 & - & {$[144]$} \\
\hline Effluent and yard trimming & - & Manual rotation & - & - & 45 & - & [66] \\
\hline
\end{tabular}

The end product, namely compost, may be used as a fertilizer/soil amendment. The quality of compost produced from $\mathrm{AD}$ effluent can be evaluated by stability and maturity parameters as well as the contents of organic matter $(\mathrm{OM}), \mathrm{N}, \mathrm{P}, \mathrm{K}$, heavy metals, and pathogens. Most previous studies showed that $\mathrm{AD}$ effluent from manure digester-based composts can have adequate $\mathrm{OM}, \mathrm{N}, \mathrm{P}$, and $\mathrm{K}$ for plant growth. Additionally, the composition was similar to those found in other composts, such as those from agro-industrial wastes and manures [13]. Stability and maturity of compost can be assessed by measuring 
the germination index and oxygen uptake rate. Troy et al.[144] studied composting of digested manure

2 and yard trimmings and showed that increasing the bulking agent from $0 \%$ to $40 \%$ significantly improved

3 the germination index from $59 \%$ to $83 \%$, indicating the composts were phytotoxin free. The oxygen

4 uptake rate was also significantly reduced during composting, indicating that the compost was stable at

5 the end of the process. The leachate produced during the composting process can be recycled or

6 depending on its composition, may be viable dilution water for AD [146].

Heavy metals in AD effluent are not removed during the composting process. In two studies,

8

there were measurable amounts of heavy metals (copper, zinc) in composts, but the concentrations did not exceed regulatory limits in the U.S. or Spain $[13,142]$. Also, pathogens (Salmonella) may survive if the composting process is too short. Franke-Whittle et al. [143] showed that a 34-day composting process was not able to completely eliminate pathogens, while 63 days of composting was successful. Another concern of land application of composted AD effluent is the possibility of odors. To overcome these challenges, a longer composting process and more aeration may be needed to induce further stabilization and reduce odorous emissions. Additionally, composting can be conducted in a closed chamber, where volatile emissions can be captured and eventually treated [11].

\subsection{Reuse of AD fibers for fuels}

$\mathrm{AD}$ effluent can be used as a solid fuel after drying and compressing into pellets, which can be used for incineration, gasification, and pyrolysis. Kratzeisen et al. [147] co-digested maize silage with different field crops and animal manure, and dried the AD effluent to 9.2-9.9\% moisture and pressed it into pellets. The AD effluent fuel pellets were an excellent solid fuel alternative, with calorific values comparable to wood pellets. Additionally, the flue gas emissions from burning AD effluent pellets were within the limits for biofuels according to the German Federal Emission Control Ordinance. Moreover, most ( $>90 \%)$ of the produced energy was provided by waste heat. Gnanendra et al. [148] studied gasification using $\mathrm{AD}$ effluent briquettes generated from the $\mathrm{AD}$ of several lignocellulosic biomasses, including agricultural residues and industrial processing residues. The produced syngas had consistent 
composition and quality acceptable for engine operation [148]. Also, the process maintained lower

2 gaseous emissions compared with incineration.

3

4

5

6

7

8

9

10

11

12

13

14

15

16

17

18

19

20

21

22

23

24

25

26

Pyrolysis is an effective method for the conversion of digested sludge into bio-oil, pyrolysis gas, and biochar [149]. The bio-oil can be upgraded into a crude oil replacement, the syngas can be used for energy, and the biochar is an effective soil conditioner. Cao and Pawlowski [149] performed an extensive review of sewage sludge pyrolysis and showed that syngas, bio-oil, and biochar formation is dependent on feedstock organic content (VS), temperature $\left(400-1000^{\circ} \mathrm{C}\right)$, reaction time $(0-45 \mathrm{~min})$, and heating rate. In a case study, Cao and Pawlowski [149] indicated that AD plus pyrolysis of anaerobically digested sewage sludge was more energy efficient (84.7\%) than direct pyrolysis of undigested sewage sludge (67.6\%). Similarly, Li et al. [150] reported on pyrolysis of AD effluent after co-digestion of chicken manure and corn stover, and suggested an $85 \%$ increase of energy recovery efficiency. However, several issues remain to be addressed by further investigations. For example, the ash content of AD effluent was usually high (15-20\%), which may cause disposal concerns [147, 148]. Additionally, AD effluent must be dried to a low moisture content $(<10 \%)$ prior to gasification, pyrolysis, or direct incineration in order to maintain energy efficiency. Besides, these systems should be built on-site of or close to the AD facilities due to the production of odor [147].

$\mathrm{AD}$ effluent, especially that from dairy manure and lignocellulosic biomass, are rich in recalcitrant fibers. These fibers can produce glucose comparable to other lignocellulosic biomass using proper pretreatment methods, which makes it a potential feedstock for bioethanol production. Following alkali pretreatment and enzymatic hydrolysis of digested dairy manure, Teater et al. [151] achieved an ethanol yield of $14.7 \mathrm{~g} \mathrm{~L}^{-1}$, a comparable value to switchgrass $\left(16.6 \mathrm{~g} \mathrm{~L}^{-1}\right)$ and corn stover $\left(18.1 \mathrm{~g} \mathrm{~L}^{-1}\right)$. Yue et al. [22] reported a 90\% glucose conversion efficiency during enzymatic hydrolysis of alkaline pretreated AD fiber, and a 72\% ethanol yield from the hydrolysate (based on theoretical ethanol yield).

Correspondingly, the authors estimated that an integrated process of $\mathrm{AD}$ and cellulosic ethanol production could produce more than 1.67 billion gallons of ethanol from 63 million dry tons of AD fiber, generated from 120 million dry tons of cattle manure available annually in the U.S. Yue et al. [152] further showed 
that dilute alkaline pretreatment was better than other pretreatment methods for treating AD fibers. The

2 authors also showed that an continuously stirred tank digesters produced better AD fibers for ethanol

3 production than plug flow digesters, because the process had $21 \%$ higher ethanol production and $33 \%$

4 higher net energy output. MacLellan et al.[153] and Yue et al.[154] investigated co-digestion of corn

5 stover with swine manure and dairy manure, and integrated the AD process with ethanol production using

6 the AD fibers. Net energy production was estimated in the range of 5.5-9.6 $\mathrm{MJ} \mathrm{kg}^{-1}$ dry raw feed.

7 Although AD effluent glucose yields were acceptable, recovery and reuse of the pretreatment chemicals

8 are required to make this process economically feasible [155].

\section{$9 \quad 5.3$ Reuse of AD fibers for materials}

particleboard production. While grass-based particleboard is a promising renewable product, a

13 hydrophobic layer on the surface of grass made up of wax, inorganic silicon, and fat, requires

14 pretreatment [20]. Pretreatment is critical when using low-cost water-based adhesives such as urea,

15 formaldehyde and protein/starch-based adhesives in particleboard production. AD could be used to

16 pretreat grasses, since extractives are degraded during AD process. Zheng et al. [20] reported an

17 integrated system producing biogas by AD of saline creeping wild ryegrass, and particleboard using the

18 AD effluent. The mechanical and long-term 24-h water resistance properties (except for modulus of elasticity) of the particleboards were significantly improved compared to those from untreated grass [20]. In the U.S., many farmers have benefited from generating animal bedding materials through

21 anaerobic digestion $[156,157]$. The solid fraction of AD effluent is low cost and rich in fiber, making it

22 an attractive bedding material. In fact, Alexander [157] reported that very little amounts of digested

23 manure are sold in the U.S. because most is reused for animal bedding [157]. Digestate from SS-AD may

24 be a better bedding material due to its lower moisture content compared with L-AD effluent. Despite the

25 potential benefits, there are issues with the use of $\mathrm{AD}$ effluent for bedding. It was shown that $\mathrm{AD}$

26 effluents have considerable levels of bacteria, which could increase the threat of infection of cattle breast 
tissue [21], which can increase milk contamination. Repeated changing of bedding materials is necessary

2 to mitigate bacterial loads when using AD effluent fibers [21].

The production of cement and aggregate from waste sludge has been thoroughly investigated [158]. Direct use of dewatered sludge as an energy source in Portland cement kilns can completely oxidize organic pollutants in sludge, and immobilize heavy metals into the final cement [158].

Additionally, the requirements of natural resources such as clay and limestone are reduced, because sludge ash is utilized in the cement [159]. However, there is little research published on the use of the solid fraction of $\mathrm{AD}$ effluent as an energy amendment for the production of cement. In a life cycle analysis, digested sludge was compared with raw sludge for use as an energy supplement in cement manufacturing. Digested sludge had a lower heating value due to the lower organic content [160], which reduced its effectiveness for reuse in cement manufacturing. However, reuse of digested sludge for concrete manufacture was more environmentally sustainable than direct incineration of digested sludge [160]. These claims should be validated through a pilot scale study using the solid fraction of AD effluent.

\section{Future recommendations}

\section{$\underline{6.1 \text { Emerging organic pollutants and treatment techniques }}$}

Besides pathogens and nutrients, growing attention has been focused on organic micro-pollutants in AD effluent and their harmful effects during land application. Studies have noted that some pharmaceuticals (e.g. Ibuprofen, Iopromide, and Diazepam), pesticides (e.g. m-Cresol), fragrances (e.g. Galaxolide), and detergents (e.g. Triclosan) are bio-transformable to some extent during the AD process, while others such as linear alkyl benzene sulphonates, nonylphenols, synthetic musks, estrogens (e.g. Estrone), and ampicillin are resistant to degradation in the AD process (Table 7) [161, 162]. Therefore, antibiotics used in dairy farming and detergents used in food could possibly exist in in AD effluent. These may cause endocrine disruption in terrestrial or aquatic ecological receptors. Most of the studies in Table 7 focused on the elimination of organic micro-pollutants, while little work has been done to investigate their degradation pathways and fates (end products). Therefore, it is difficult to evaluate the risks of land 
1 applying AD effluent that contains these pollutants. Another concern about organic micro-pollutants is

2 that they may negatively affect AD efficiency. It was observed that some antibiotics such as ampicillin,

3 florfenicol, sulfamethazine, and tylosin can inhibit AD microbes, retard degradation of other compounds,

4 and decrease biogas productivity [163]. Understanding the effects of emerging organic micro-pollutants

5 on the utilization of AD effluent is challenging. This is because there are technical hurdles in

6 characterization of the vast number of pollutants during AD and land application of the effluent.

7 Advanced oxidation has been employed to reduce the concentration of emerging organic micro-

8 pollutants in $\mathrm{AD}$. Carballa et al. [164] examined the influence of ozone pre-treatment on sludge AD, and

9 showed that emerging organic micro-pollutants were removed with efficiencies ranging from $20 \%$ to $99 \%$.

10 However, the dewatering properties of sludge were deteriorated when the ozone pre-treatment was

11 applied. Other oxidative pretreatment methods, such as oxidation using air and $\mathrm{Fe}^{2+}$ at high temperatures

12 and elevated pressures have been used for wet sludge disintegration [165], but may also have the potential

13 to be applied for the removal of organic micro-pollutants in AD effluent. Incineration can be another

14 alternative, but requires dewatering. One major concern of all the above mentioned methods is the cost.

15 Therefore, feasibility studies are needed.

Table 7: Behavior of emerging organic micro-pollutants during AD and after land application

\begin{tabular}{lcclc}
\hline Pollutant & Formula & \multicolumn{2}{c}{ Application Behavior during AD and after land application } & Ref. \\
\hline Ampicillin & $\mathrm{C}_{16} \mathrm{H}_{19} \mathrm{~N}_{3} \mathrm{O}_{4} \mathrm{~S}$ & Antibiotic & $\begin{array}{l}\text { Not degradable, can be inhibitory to AD at high } \\
\text { concentrations. }\end{array}$ & {$[163]$} \\
Bezafibrate & $\mathrm{C}_{19} \mathrm{H}_{20} \mathrm{ClNO}_{4}$ & Medicine & Moderately degraded in AD, unknown end-product & {$[166]$} \\
Bisphenol A & $\mathrm{C}_{15} \mathrm{H}_{16} \mathrm{O}_{2}$ & Resins & Moderately degraded in AD & {$[167]$} \\
$\begin{array}{l}\text { Bis (2-Ethylhexyl) } \\
\text { Phthalate }\end{array}$ & $\mathrm{C}_{24} \mathrm{H}_{38} \mathrm{O}_{4}$ & Plastics & Not tested in AD; possibly degradable in soil. & {$[168]$} \\
Butanone & $\mathrm{C}_{4} \mathrm{H}_{8} \mathrm{O}$ & Solvent & $\begin{array}{l}\text { Not tested in AD; possibly volatile in soil. } \\
\text { m-Cresol }\end{array}$ \\
$\mathrm{C}_{7} \mathrm{H}_{8} \mathrm{O}$ & Pesticide & $\begin{array}{l}\text { Moderately degraded in AD, unknown end-product; inhibited } \\
\text { soil ammonia oxidizing bacteria. }\end{array}$ & {$[169]$} \\
Estrone & $\mathrm{C}_{18} \mathrm{H}_{22} \mathrm{O}_{2}$ & Hormone & $\begin{array}{l}\text { Poorly degraded in AD, unknown end-product; persisting in } \\
\text { soil. }\end{array}$ & {$[171]$} \\
Galaxolide & $\mathrm{C}_{18} \mathrm{H}_{26} \mathrm{O}$ & Fragrance & $\begin{array}{l}\text { Moderately degraded in AD, unknown end-product; possible } \\
\text { crop uptake. }\end{array}$ \\
Ibuprofen & $\mathrm{C}_{13} \mathrm{H}_{18} \mathrm{O}_{2}$ & Medicine & $\begin{array}{l}\text { Moderately degraded in AD, unknown end-product; no crops } \\
\text { uptake. }\end{array}$ \\
Naproxen & $\mathrm{C}_{14} \mathrm{H}_{14} \mathrm{O}_{3}$ & Medicine & Moderately degraded in AD & M74] \\
\hline
\end{tabular}


Toluene

$\mathrm{C}_{7} \mathrm{H}_{8} \quad$ Solvent, fuelCompletely degraded in AD.

Triclosan

$\mathrm{C}_{12} \mathrm{H}_{7} \mathrm{Cl}_{3} \mathrm{O}_{2}$

Moderately degraded in AD, unknown end-product; rapidly dissipated in soil.

$[176,177]$

6.2 Pathogen regrowth

2

Although AD can be an effective method for pathogen stabilization, there is also evidence of insufficient pathogen destruction. For example, Alfa et al. [178] showed that while E.coli and Shigella sp. were effectively removed via AD, while species of Salmonella and Klebsiella survived. Additionally, Fu et al. [179] indicated that the AD process may only alter the culturable state of microorganisms, rather than killing them. The use of cattle manure AD effluent also poses risk, due to the wide use of antimicrobial drugs in cattle farming. This could result in formation of multi-drug resistant bacteria, as identified in AD effluent by Resende et al. [180]. Traditional processing methods may affect regrowth of harmful microbes from AD effluent. For example, regrowth of fecal coliforms, E. coli and Enterococci occurred after Chen et al. [181] dewatered thermophilic and mesophilic AD effluent by centrifugation [181]. In a similar study, Erkan and Sanin [182] showed that belt filter dewatering caused 0.6 log decreases in indicator organisms, while 0.7-1.4 log increases occurred after centrifugation. Contrarily, the introduction of effluent to the soil can improve bacterial decomposer communities and improve nutrient cycling [183]. Still, to reduce public health risks, development of low cost monitoring techniques via molecular (DNA, RNA) methods is critical. If the issue of pathogen regrowth is widespread, AD effluent may require further stabilization by energy intensive methods (thermophilic aerobic digestion, pasteurization). Still, the heating demands for further stabilization could be obtained via waste heat produced during the combustion of biogas. Researchers should continue to monitor the effects of pathogens, an issue that has limited the area available for land application (Section 2.3).

\section{Summary and Conclusions}

Widespread adoption of anaerobic digestion for bioenergy production may be limited by the massive quantities of AD effluent produced. Agronomic land application has been the primary AD effluent management technique. However, environmental restrictions due to pathogen accumulation, food safety, and nutrient runoff have necessitated the development of alternative technologies for AD effluent 
handling. The economic and environmental concerns related to land application of AD effluent could be

2 combatted by using emerging treatment technologies. Aside from land application, there are few

3 techniques to directly reuse or manage AD effluent. While $\mathrm{AD}$ effluent is a viable inoculum source for

4 solid state anaerobic digestion, the solid-state anaerobic digestate is easy to handle and can be composted

5 for fertilizer.

6 Dewatering techniques such as centrifugation have been used at large scale facilities to partition

7 raw AD effluent into liquid and solid fractions that are easier to handle and transport. Recently,

8 evaporation has been used to further reduce $\mathrm{AD}$ effluent volume and $\mathrm{DAF}$ is an effective method to

9 remove solids. However, the high energy demands of mechanical separation and evaporation may limit

10 their adoption to large scale $\mathrm{AD}$ facilities that produce excess quantities of electricity and process heat.

11 Smaller scale facilities could use less energy intensive methods such as passive filtration [10, 69, 70].

12 Still, the variability of water distribution in AD effluent may negatively influence dewatering efficiency.

13 For instance, the colloidal particles in digested manure may not be easily separated without polymer

14 addition [184]. Therefore, techno-economic and life cycle comparisons of dewatering techniques are 15 needed.

The liquid fraction is commonly used for irrigation, but concerns about volatile TAN emissions

17 and nutrient runoff may reduce the acceptance of this activity. The water could be reused for industrial

18 processes such as bioethanol, but limited pilot scale research is available. Residual organics could be

19 converted to renewable electricity in MFCs. However, low quantities of degradable organics may limit

20 efficiency and power output. Thus, activated sludge technology seems most feasible for organics removal

21 prior to discharge. Dissolved nutrients in the liquid fraction provide the greatest opportunity for

22 valorization. Currently, physiochemical technologies such as ammonia stripping/absorption, reverse

23 osmosis, and struvite crystallization have successfully produced nitrogen and phosphate fertilizers from

24 the liquid fraction at pilot and full scale $[90,102,108]$. Digested manures have high TAN, indicating large

25 volumes of ammonium based fertilizers could be produced by ammonia stripping/absorption and reverse

26 osmosis. However, ammonia stripping/absorption has significant energy demands and reverse osmosis is 
1 known for high capital costs. Thus, the success of these technologies will be dependent on the scale of

2 operation and cost of energy. Struvite crystallization may not be feasible for digested manure and food

3 waste because of low dissolved P content. Additionally, the need for exogenous magnesium may reduce

4 economic feasibility. Reuse of nutrients for hydroponics and algae culture show good potential, but

5 require significantly more research about food safety and microbial contamination, respectively.

6 Additionally, limited pilot scale data indicate hydroponics and algae culture will be more applicable in the

7 long-term. ANAMMOX appears to have potential for sustainable removal of $\mathrm{N}$ in the liquid fraction.

8 However, the life cycle impacts of removing reactive $\mathrm{N}$ requires assessment.

9 Composting is an effective method to remove pathogens and reduce the volume of the solid

10 fraction of AD effluent. Additionally, the production of compost offers considerable value. Furthermore,

11 raw $\mathrm{AD}$ effluent can be integrated in the composting process and composting leachate can be used for $\mathrm{AD}$

12 dilution water. The major downside to composting is the cost of aeration and long treatment times.

13 However, composting remains a feasible technology for management of the solid fraction of AD effluent.

14 The solid fraction could also be used as a feedstock for fuels, but the cost of pretreatment (enzymatic

15 hydrolysis, drying) may limit the economic viability of this practice The use of AD effluent for animal

16 bedding has increased in recent years. However, there is need to study the impact of bedding on animal

17 health. Use of the solid fraction for particle board and cement production is intriguing, but there is a lack

18 of pilot scale research. Table 8 provides a summary of the emerging methods for AD effluent treatment.

Table 8: Comparison of emerging technologies for treatment of AD effluent

\begin{tabular}{ccccc}
\hline Treatment Process & Adapted for & Scale & Advantages & Disadvantages \\
\hline $\begin{array}{c}\text { Reuse as AD } \\
\text { inoculum }\end{array}$ & Raw effluent & Bench/Pilot/Full & $\begin{array}{c}\text { Uses whole mass of } \\
\text { AD effluent, } \\
\text { stabilizes AD } \\
\text { process }\end{array}$ & $\begin{array}{c}\text { Total mass of AD } \\
\text { effluent not reduced }\end{array}$ \\
Microbial fuel cells & Liquid fraction & Bench & $\begin{array}{c}\text { Organics removal, } \\
\text { electricity } \\
\text { production }\end{array}$ & $\begin{array}{c}\text { Low power output, } \\
\text { limited pilot scale } \\
\text { study }\end{array}$ \\
$\begin{array}{c}\text { Freshwater recycle } \\
\text { for ethanol }\end{array}$ & Liquid fraction & Bench & $\begin{array}{c}\text { Reuse of freshwater, } \\
\text { biofuel production }\end{array}$ & $\begin{array}{c}\text { Microbial } \\
\text { contamination, }\end{array}$
\end{tabular}




\begin{tabular}{|c|c|c|c|c|}
\hline production & & & & $\begin{array}{l}\text { limited pilot scale } \\
\text { study }\end{array}$ \\
\hline ANAMMOX & Liquid fraction & Pilot/Full & $\begin{array}{l}\text { Produces harmless } \\
\mathrm{N}_{2} \text { gas, low energy } \\
\text { requirements }\end{array}$ & $\begin{array}{c}\text { Microbial } \\
\text { contamination, Loss } \\
\text { of reactive N }\end{array}$ \\
\hline Ammonia stripping & Liquid fraction & Pilot/Full & $\begin{array}{l}\text { High } \mathrm{NH}_{3} \text { removal } \\
\text { efficiencies, } \\
\mathrm{NH}_{3} \text { in outlet stream } \\
\text { can be converted to } \\
\text { fertilizer }\end{array}$ & $\begin{array}{l}\text { High energy inputs, } \\
\text { need for } \mathrm{pH} \text { control }\end{array}$ \\
\hline Reverse osmosis & Liquid fraction & Pilot/Full & $\begin{array}{c}\text { High } \mathrm{NH}_{4}^{+} \text {removal } \\
\text { efficiencies, } \\
\mathrm{NH}_{4}^{+} \text {in retentate } \\
\text { can be used as } \\
\text { fertilizer, } \\
\text { other products } \\
\text { (VFAs, potassium) } \\
\text { recovered in } \\
\text { retentate }\end{array}$ & $\begin{array}{l}\text { High membrane } \\
\text { costs, high energy } \\
\text { demands, need for } \\
\text { pH control }\end{array}$ \\
\hline $\begin{array}{c}\text { Struvite } \\
\text { crystallization }\end{array}$ & Liquid fraction & Pilot/Full & $\begin{array}{c}\text { High } \mathrm{NH}_{4}^{+} \text {and } \\
\text { dissolved P removal } \\
\text { efficiencies, } \\
\text { produces solid } \\
\text { fertilizer }\end{array}$ & $\begin{array}{l}\text { Need for Mg input, } \\
\text { agricultural effluents } \\
\text { have low dissolved } \\
\mathrm{Mg} \text { and } \mathrm{P} \text { content }\end{array}$ \\
\hline Hydroponics & Liquid fraction & Bench & $\begin{array}{l}\text { Control over } \\
\text { nutrient loading, } \\
\text { production of } \\
\text { valuable crops }\end{array}$ & $\begin{array}{c}\text { Microbial } \\
\text { contamination, } \\
\text { food safety concerns }\end{array}$ \\
\hline Algae production & Liquid fraction & Bench/pilot & $\begin{array}{c}\text { Reuse of N, } \\
\text { biofuel production }\end{array}$ & $\begin{array}{c}\text { Microbial } \\
\text { contamination, } \\
\text { high costs of } \\
\text { biomass processing }\end{array}$ \\
\hline Composting & $\begin{array}{l}\text { Raw effluent, Solid } \\
\text { fraction }\end{array}$ & Pilot/Full & $\begin{array}{l}\text { Pathogen removal, } \\
\text { compost production }\end{array}$ & $\begin{array}{l}\text { Long treatment } \\
\text { times, } \\
\text { air emissions }\end{array}$ \\
\hline $\mathrm{AD}$ fibers for fuels & Solid fraction & Bench & Biofuel production & $\begin{array}{c}\text { Need for } \\
\text { pretreatment, high } \\
\text { energy demands }\end{array}$ \\
\hline Animal bedding & Solid fraction & Pilot/full & $\begin{array}{l}\text { Complete reuse of } \\
\text { fibers, low costs }\end{array}$ & $\begin{array}{c}\text { Microbial } \\
\text { contamination, } \\
\text { animal health } \\
\text { concerns }\end{array}$ \\
\hline $\begin{array}{c}\text { AD fibers for } \\
\text { building materials }\end{array}$ & Solid fraction & Bench & $\begin{array}{l}\text { Complete reuse of } \\
\text { fibers, valuable } \\
\text { materials }\end{array}$ & $\begin{array}{c}\text { Need for } \\
\text { pretreatment, high } \\
\text { energy demands }\end{array}$ \\
\hline
\end{tabular}

3 during and after land application of $\mathrm{AD}$ effluent. Overall, the combination of agronomic land application

4 and emerging technologies could provide unique waste handling solutions to the growing bioenergy 
1 industry. Further study at pilot and large scales could provide significant advances that promote AD

2 adoption and environmental sustainability.

\section{Acknowledgements}

4 This project was funded by USDA NIFA Biomass Research and Development Initiative Program (Award

5 no. 2012-10008-20302). The authors would like to thank Mrs. Mary Wicks for conducting a thorough

6 review and providing thoughtful comments on this manuscript. The authors also thank Dr. Fuqing Xu for

7 valuable comments.

[1] Food Waste. Projects Using Food Waste to Make Biogas. American Biogas Council; 2014. https://www.americanbiogascouncil.org/biogas_foodWaste.asp.

[2] National Program 206: Manure and Byproduct Utilization. Annual Report Manure and Byproduct Utilization. USDA; 2005.

http://www.ars.usda.gov/research/programs/programs.htm?np_code=206\&docid=13337

27 [3] Li YB, Park SY, Zhu JY. Solid-state anaerobic digestion for methane production from organic waste. Renew Sustain Energy Rev 2011;15:821-6. 
[4] Yang L, Ge X, Wan C, Yu F, Li Y. Progress and perspectives in converting biogas to transportation fuels. Renew Sustain Energy Rev 2014;40:1133-52.

[5] Nkoa R. Agricultural benefits and environmental risks of soil fertilization with anaerobic digestates: a review. Agron Sustain Dev 2014;34:473-92.

[6] Agstar. Operating Anaerobic Digester Projects. Farm Project Profiles. USEPA; 2015. http://www.epa.gov/agstar/projects/

[7] Agstar. Market Opportunities for Biogas Recovery Systems at U.S. Livestock Facilities.USEPA: 2011. http://www.epa.gov/agstar/documents/biogas_recovery_systems_screenres.pdf

[8] USEPA. Reducing Wasted Food Basics; 2015. http://www2.epa.gov/recycle/reducing-wasted$\underline{\text { food-basics }}$

[9] Yiridoe EK, Gordon R, Brown BB. Nonmarket cobenefits and economic feasibility of on-farm biogas energy production. Energy Policy 2009;37:1170-9.

[10] Rehl T, Müller J. Life cycle assessment of biogas digestate processing technologies. Resour Conserv Recy 2011;56:92-104.

[11] Metcalf \& Eddy. Wastewater Engineering: Treatment and Reuse. $4^{\text {th }}$ ed. Boston: McGraw-Hill; 2003.

[12] Le Corre KS, Valsami-Jones E, Hobbs P, Parsons SA. Phosphorus recovery from wastewater by struvite crystallization: A review. Crit Rev Env Sci Technol 2009;39:433-77.

[13] Bustamante MA, Alburquerque JA, Restrepo AP, de la Fuente C, Paredes C, Moral R, et al. Cocomposting of the solid fraction of anaerobic digestates, to obtain added-value materials for use in agriculture. Biomass Bioenergy 2012;43:26-35.

[14] Uludag-Demirer S, Demirer GN, Chen S. Ammonia removal from anaerobically digested dairy manure by struvite precipitation. Process Biochem 2005;40:3667-74.

[15] Guštin S, Marinšek-Logar R. Effect of $\mathrm{pH}$, temperature and air flow rate on the continuous ammonia stripping of the anaerobic digestion effluent. Process Saf Environ 2011;89:61-6.

[16] Masse L, Massé DI, Pellerin Y. The effect of $\mathrm{pH}$ on the separation of manure nutrients with reverse osmosis membranes. J Membr Sci 2008;325:914-9.

[17] Zhang CM, Mao ZG, Wang X, Zhang JH, Sun FB, Tang L, et al. Effective ethanol production by reutilizing waste distillage anaerobic digestion effluent in an integrated fermentation process coupled with both ethanol and methane fermentations. Bioprocess Biosyst Eng 2010;33:1067-75.

[18] Cai T, Park SY, Li YB. Nutrient recovery from wastewater streams by microalgae: Status and prospects. Renew Sustain Energy Rev 2013;19:360-9.

[19] Krishnasamy K, Nair J, Bauml B. Hydroponic system for the treatment of anaerobic liquid. Water Sci Technol 2012;65:1164-71. 
[20] Zheng Y, Pan ZL, Zhang RH, El-Mashad HM, Pan JM, Jenkins BM. Anaerobic digestion of saline creeping wild ryegrass for biogas production and pretreatment of particleboard material. Bioresour Technol 2009;100:1582-8.

[21] Blowey R, Wookey J, Russell L. Dried manure solids as a bedding material for dairy cows. Vet Rec 2013;173:99.

[22] Yue ZB, Teater C, Liu Y, MacLellan J, Liao W. A sustainable pathway of cellulosic ethanol production integrating anaerobic digestion with biorefining. Biotechnol Bioeng 2010;105:1031-9.

[23] APHA. Standard Methods for the Examination of Water and Wastewater. American Public Health Association. 21st ed. Washington, D.C; 2005.

[24] Rigby H, Smith SR. Nitrogen availability and indirect measurements of greenhouse gas emissions from aerobic and anaerobic biowaste digestates applied to agricultural soils. Waste Manage 2013 ;33:2641-52.

[25] Abubaker J, Risberg K, Pell M. Biogas residues as fertilisers - Effects on wheat growth and soil microbial activities. Appl Energy 2012;99:126-34.

[26] Pezzolla D, Bol R, Gigliotti G, Sawamoto T, Lopez AL, Cardenas L, et al. Greenhouse gas (GHG) emissions from soils amended with digestate derived from anaerobic treatment of food waste. Rapid Commun Mass Spectrom 2012;26:2422-30.

[27] Haraldsen TK, Andersen U, Krogstad T, Sørheim R. Liquid digestate from anaerobic treatment of source-separated household waste as fertilizer to barley. Waste Manage Res 2011;29:1271-6.

[28] Fouda S, von Tucher S, Lichti F, Schmidhalter U. Nitrogen availability of various biogas residues applied to ryegrass. J Plant Nutr Soil Sci 2013;176:572-84.

[29] Alburquerque JA, de la Fuente C, Bernal MP. Chemical properties of anaerobic digestates affecting $\mathrm{C}$ and $\mathrm{N}$ dynamics in amended soils. Agr Ecosyst Environ 2012;160:15-22.

[30] Alburquerque JA, de la Fuente C, Ferrer-Costa A, Carrasco L, Cegarra J, Abad M, et al. Assessment of the fertiliser potential of digestates from farm and agroindustrial residues. Biomass Bioenergy 2012;40:181-9.

[31] Gagnon B, Ziadi N, Chantigny MH, Bélanger G, Massé DI. Biosolids from treated swine manure and papermill residues affect corn fertilizer value. Agron J 2012;104:483-92.

[32] Zhang Y, Banks CJ, Heaven S. Anaerobic digestion of two biodegradable municipal waste streams. J Environ Manage 2012;104:166-74.

[33] Banks CJ, Chesshire M, Heaven S, Arnold R. Anaerobic digestion of source-segregated domestic food waste: Performance assessment by mass and energy balance. Bioresour Technol 2011;102:612-20.

[34] Loria ER, Sawyer JE. Extractable soil phosphorus and inorganic nitrogen following application of raw and anaerobically digested swine manure. Agron J 2005;97:879-85. 
[35] Teglia C, Tremier A, Martel J. Characterization of solid digestates: Part 2, Assessment of the quality and suitability for composting of six digested products. Waste Biomass Valoriz 2011;2:113-26.

[36] Duan GL, Zhang HM, Liu YX, Jia Y, Hu Y, Cheng WD. Long-term fertilization with pig-biogas residues results in heavy metal accumulation in paddy field and rice grains in Jiaxing of China. Soil Sci Plant Nutr 2012;58:637-46.

[37] Demirel B, Gol NP, Onay TT. Evaluation of heavy metal content in digestate from batch anaerobic co-digestion of sunflower hulls and poultry manure. J Mater Cycles Waste Manage 2013;15:242-6.

[38] Möller K, Müller T. Effects of anaerobic digestion on digestate nutrient availability and crop growth: A review. Eng Life Sci 2012;12:242-57.

[39] Cherosky P, Li Y. Hydrogen sulfide removal from biogas by bio-based iron sponge. Biosyst Eng 2013;114:55-9.

[40] USEPA. A Plain English Guide to the EPA Part 503 Biosolids Rule.Washington, DC: Office of Wastewater Management; 1994.

[41] Sahlström L. A review of survival of pathogenic bacteria in organic waste used in biogas plants. Bioresour Technol 2003;87:161-6.

[42] Labatut RA, Angenent LT, Scott NR. Conventional mesophilic vs. thermophilic anaerobic digestion: A trade-off between performance and stability? Water Res 2014;53:249-58.

[43] Bougnom BP, Niederkofler C, Knapp BA, Stimpfl E, Insam H. Residues from renewable energy production: Their value for fertilizing pastures. Biomass Bioenergy 2012;39:290-5.

[44] Yu FB, Luo XP, Song CF, Zhang MX, Shan SD. Concentrated biogas slurry enhanced soil fertility and tomato quality. Acta Agr Scand B-S P 2010;60:262-8.

[45] Sieling K, Herrmann A, Wienforth B, Taube F, Ohl S, Hartung E, et al. Biogas cropping systems: Short term response of yield performance and $\mathrm{N}$ use efficiency to biogas residue application. Eur J Agron 2013;47:44-54.

[46] Svensson K, Odlare M, Pell M. The fertilizing effect of compost and biogas residues from source separated household waste. J Agr Sci 2004;142:461-7.

[47] Walsh JJ, Jones DL, Edwards-Jones G, Williams AP. Replacing inorganic fertilizer with anaerobic digestate may maintain agricultural productivity at less environmental cost. J Plant Nutr Soil Sci 2012;175:840-5.

[48] Bachmann S, Wentzel S, Eichler-Löbermann B. Codigested dairy slurry as a phosphorus and nitrogen source for Zea mays L. and Amaranthus cruentus L. J Plant Nutr Soil Sci 2011;174:90815.

[49] Loria ER, Sawyer JE, Barker DW, Lundvall JP, Lorimor JC. Use of anaerobically digested swine manure as a nitrogen source in corn production. Agron J 2007;99:1119-29. 
[50] Möller K, Stinner W, Deuker A, Leithold G. Effects of different manuring systems with and without biogas digestion on nitrogen cycle and crop yield in mixed organic dairy farming systems. Nutr Cycl Agroecosys 2008;82:209-32.

[51] Chantigny MH, Angers DA, Bélanger G, Rochette P, Eriksen-Hamel N, Bittman S, et al. Yield and nutrient export of grain corn fertilized with raw and treated liquid swine manure. Agron J 2008;100:1303-9.

[52] Vaneeckhaute C, Ghekiere G, Michels E, Vanrolleghem PA, Meers E, Tack F. Nutrient recovery from biodigestion waste (water) streams and reuse as renewable fertilizers: a two-year field experiment. WEF/IWA Nutrient Removal and Recovery, Conference proceedings. Water Environment Federation (WEF); International Water Association (IWA); 2013.

[53] USFDA. Food Saftey Modernization Act: FSMA Facts. Background on the FDA Food Safety Modernization Act. 2011. p. 1-3. http://www.fda.gov/downloads/Food/GuidanceRegulation/UCM263773.pdf

[54] Lukicheva I, Pagilla K, Tian G, Cox A, Granato T. Enhanced stabilization of digested sludge during long-term storage in anaerobic lagoons. Water Environ Res 2014;86:291-5.

[55] Johansen A, Carter MS, Jensen ES, Hauggard-Nielsen H, Ambus P. Effects of digestate from anaerobically digested cattle slurry and plant materials on soil microbial community and emission of $\mathrm{CO}_{2}$ and $\mathrm{N}_{2} \mathrm{O}$. Appl Soil Ecol 2013;63:36-44.

[56] Delzeit R, Kellner U. The impact of plant size and location on profitability of biogas plants in Germany under consideration of processing digestates. Biomass Bioenergy 2013;52:43-53.

[57] Lukehurst CT, Frost P, Al Seadi T. Utilisation of digestate from biogas plants as biofertiliser. IEA Bioenergy; 2010. http://www.iea-biogas.net/files/daten-redaktion/download/publitask37/Digestate Brochure Revised 12-2010.pdf

[58] Zhu J, Zheng, Y, Xu, F, Li, Y. Solid-state anaerobic co-digestion of hay and soybean processing waste for biogas production. Bioresour Technol 2014; 154: 240-7.

[59] Forster-Carneiro T, Pérez M, Romero LI, Sales D. Dry-thermophilic anaerobic digestion of organic fraction of the municipal solid waste: Focusing on the inoculum sources. Bioresour Technol 2007;98:3195-203.

[60] Estevez MM, Sapci Z, Linjordet R, Schnürer A, Morken J. Semi-continuous anaerobic codigestion of cow manure and steam-exploded Salix with recirculation of liquid digestate. $\mathbf{J}$ Environ Manag 2014;136:9-15.

[61] Shi J, Xu F, Wang Z, Stiverson JA, Yu Z, Li Y. Effects of microbial and non-microbial factors of liquid anaerobic digestion effluent as inoculum on solid-state anaerobic digestion of corn stover. Bioresour Technol 2014;157:188-96.

[62] Gu Y, Chen X, Liu Z, Zhou X, Zhang Y. Effect of inoculum sources on the anaerobic digestion of rice straw. Bioresour Technol 2014;158:149-55. 
[63] Pozdniakova TA, Costa JC, Santos RJ, Alves MM, Boaventura RA. Anaerobic biodegradability of Category 2 animal by-products: Methane potential and inoculum source. Bioresour Technol 2012;124:276-82.

[64] Xu F, Shi J, Lv W, Yu Z, Li Y. Comparison of different liquid anaerobic digestion effluents as inocula and nitrogen sources for solid-state batch anaerobic digestion of corn stover. Waste Manage 2013;33:26-32.

[65] Nordberg A, Jarvis A, Stenberg B, Mathisen B, Svensson BH. Anaerobic digestion of alfalfa silage with recirculation of process liquid. Bioresour Technol 2007;98:104-11.

[66] Rumer A. Quasar Energy's groundbreaking work might come with a price. Zanesville Times Recorder; 2014 Jun 14. http://www.zanesvilletimesrecorder.com/article/20140613/NEWS01/306130040/Quasar-Energys-groundbreaking-work-might-come-with-a-price

[67] Davis ML. Water and Wastewater Engineering. $1^{\text {st }}$ ed. New York: McGraw-Hill; 2010.

[68] Mahmoud A, Olivier J, Vaxelaire J, Hoadley AFA. Advances in Mechanical Dewatering of Wastewater Sludge Treatment. In: Sharma SK, Sanghi R, editors. Wastewater Reuse and Management, New York: Springer; 2013. p. 253-303.

[69] Xia M, Tao W, Shayya W, Lu Z. Passive solid-liquid separation of anaerobically digested dairy manure using two-stage filtration. Biosyst Eng 2012; 111: 392-7.

[70] Fuchs W, Drosg B. Assessment of the state of the art of technologies for the processing of digestate residue from anaerobic digesters. Water Sci Technol 2013; 67: 1984-93.

[71] Pant D, Van Bogaert G, Diels L, Vanbroekhoven K. A review of the substrates used in microbial fuel cells (MFCs) for sustainable energy production. Bioresour Technol 2010;101:1533-43.

[72] Dosta J, Rovira J, Gali A, Macé S, Mata-Alvarez J. Integration of a Coagulation/Flocculation step in a biological sequencing batch reactor for COD and nitrogen removal of supernatant of anaerobically digested piggery wastewater. Bioresour Technol 2008;99:5722-30.

[73] Ge Z, Zhang F, Grimaud J, Hurst J, He Z. Long-term investigation of microbial fuel cells treating primary sludge or digested sludge. Bioresour Technol 2013;136:509-14.

[74] Inglesby AE, Fisher AC. Enhanced methane yields from anaerobic digestion of Arthrospira maxima biomass in an advanced flow-through reactor with an integrated recirculation loop microbial fuel cell. Energy Environ Sci 2012;5:7996-8006.

[75] Gong W, Li WZ, Liang H. Application of A/O-MBR for treatment of digestate from anaerobic digestion of cow manure. J Chem Technol Biotechnol 2010; 85: 1334-9.

[76] Zhang CM, Jiang L, Mao Z, Zhang J, Tang L. Effects of propionic acid and pH on ethanol fermentation by Saccharomyces cerevisiae in cassava mash. Appl Biochem Biotechnol 2011;165:883-91. 
[77] Wang K, Jiang L, Mao Z, Zhang C, Zhang J, Zhang H. The effect of sulfide and ammonia on cassava fermentation for ethanol production in an ethanol-methane coupled system. Water Sci Technol 2011;64:2066-71.

[78] Wang K, Zhang J, Liu P, Cao H, Mao Z. Reusing a mixture of anaerobic digestion effluent and thin stillage for cassava ethanol production. J Clean Prod 2014;75:57-63.

[79] Gao T, Li X. Using thermophilic anaerobic digestate effluent to replace freshwater for bioethanol production. Bioresour Technol 2011;102:2126-9.

[80] Xu J, Chen Y, Zhang H, Tang L, Wang K, Zhang J, et al. Production of citric acid using its extraction wastewater treated by anaerobic digestion and ion exchange in an integrated citric acid-methane fermentation process. Bioprocess Biosyst Eng 2014; 37: 1659-68.

[81] Passanha P, Esteves SR, Kedia G, Dinsdale RM, Guwy AJ. Increasing polyhydroxyalkanoate (PHA) yields from Cupriavidus necator by using filtered digestate liquors. Bioresour Technol 2013;147:345-52.

[82] Obaja D, Macé S, Costa J, Sans C, Mata-Alvarez J. Nitrification, denitrification and biological phosphorus removal in piggery wastewater using a sequencing batch reactor. Bioresour Technol 2003;87:103-11.

[83] Jetten MSM, van Niftrik L, Strous M, Kartal B, Keltjens JT, Op den Camp HJM. Biochemistry and molecular biology of anammox bacteria. Crit Rev Biochem Mol Biol 2009;44:65-84.

[84] Zhang M, Lawlor PG, Wu G, Lynch B, Zhan X. Partial nitrification and nutrient removal in intermittently aerated sequencing batch reactors treating separated digestate liquid after anaerobic digestion of pig manure. Bioprocess Biosyst Eng 2011;34:1049-56.

[85] Magrí A, Béline F, Dabert P. Feasibility and interest of the anammox process as treatment alternative for anaerobic digester supernatants in manure processing - An overview. J Environ Manage 2013;131:170-84.

[86] Wen J, Tao W, Wang Z, Pei Y. Enhancing simultaneous nitritation and anammox in recirculating biofilters: Effects of unsaturated zone depth and alkalinity dissolution of packing materials. J Haz Mat 2013; 244:671-80.

[87] Joss A, Salzgeber D, Eugster J, Konig R, Rottermann K, Burger S, et al. Full-scale nitrogen removal from digester liquid with partial nitritation and anammox in one SBR. Environ Sci Technol 2009;43:5301-6.

[88] Strous M, Van Gerven E, Kuenen JG, Jetten M. Effects of aerobic and microaerobic conditions on anaerobic ammonium-oxidizing (Anammox) sludge. Appl Environ Microbiol 1997;63:2446-8.

[89] Jiang A, Zhang T, Zhao Q, Frear C, Chen S. Integrated Ammonia Recovery Technology in Conjunction with Dairy Anaerobic Digestion. Climate Friendly Farming. CSANR Research Report 2010-2001; 2010. 
[90] De la Rubia MA, Walker M, Heaven S, Banks CJ, Borja R. Preliminary trials of in situ ammonia stripping from source segregated domestic food waste digestate using biogas: Effect of temperature and flow rate. Bioresour Technol 2010;101:9486-92.

[91] Serna-Maza A, Heaven S, Banks CJ. Ammonia removal in food waste anaerobic digestion using a side-stream stripping process. Bioresour Technol 2014;152:307-15.

[92] Jiang A, Zhang T, Zhao Q, Li X, Chen S, Frear CS. Evaluation of an integrated ammonia stripping, recovery, and biogas scrubbing system for use with anaerobically digested dairy manure. Biosyst Eng 2014;119:117-26.

[93] Hadlocon LJ, Manuzon RB, Zhao L. Development and evaluation of a full-scale spray scrubber for ammonia recovery and production of nitrogen fertilizer at poultry facilities. Environ Technol $2015 ; 36: 405-16$.

[94] Desloover J, Woldeyohannis AA, Verstraete W, Boon N, Rabaey K. Electrochemical resource recovery from digestate to prevent ammonia toxicity during anaerobic digestion. Environ Sci Technol 2012;46:12209-16.

[95] Noworyta A, Koziol T, Trusek-Holownia A. A system for cleaning condensates containing ammonium nitrate by the reverse osmosis method. Desalination 2003;156:397-402.

[96] Kurniawan TA, Lo WH, Chan GYS. Physico-chemical treatments for removal of recalcitrant contaminants from landfill leachate. J Hazard Mater 2006;129:80-100.

[97] De Gisi S, Galasso M, De Feo G. Treatment of tannery wastewater through the combination of a conventional activated sludge process and reverse osmosis with a plane membrane. Desalination 2009;249:337-42.

[98] Häyrynen K, Pongrácz E, Väisänen V, Pap N, Mänttäri M, Langwaldt J, et al. Concentration of ammonium and nitrate from mine water by reverse osmosis and nanofiltration. Desalination 2009;240:280-9.

[99] Fu G, Cai T, Li Y. Concentration of ammoniacal nitrogen in effluent from wet scrubbers using reverse osmosis membrane. Biosyst Eng 2011;109:235-40.

[100] Bilstad T, Madland M, Espedal E, Hanssen PH. Membrane Separation of Raw and Anaerobically Digested Pig Manure. Water Sci Technol 1992;25:19-26.

[101] Vaneeckhaute C, Meers E, Michels E, Christiaens P, Tack FMG. Fate of macronutrients in water treatment of digestate using vibrating reversed osmosis. Water Air Soil Pollut 2012;223:1593603.

[102] Zacharof MP, Lovitt RW. Complex effluent streams as a potential source of volatile fatty acids. Waste Biomass Valor 2013;4:557-81.

[103] Rahman MM, Salleh MAM, Rashid U, Ahsan A, Hossain MM, Ra CS. Production of slow release crystal fertilizer from wastewaters through struvite crystallization - A review. Arab J Chem 2014;7:139-55. 
[104] Johnston AE, Richards IR. Effectiveness of different precipitated phosphates as phosphorus sources for plants. Soil Use Manage 2003;19:45-9.

[105] Ariyanto E, Sen TK, Ang HM. The influence of various physico-chemical process parameters on kinetics and growth mechanism of struvite crystallisation. Adv Powder Technol 2014;25:682-94.

[106] Koch FA, Mavinic DS, Yonemitsu N, Britton AT; Fluidized Bed Wastewater Treatment. US patent 7,622,047; 2009.

[107] Britton A, Koch FA, Mavinic DS, Adnan A, Oldham WK, Udala B. Pilot-scale struvite recovery from anaerobic digester supernatant at an enhanced biological phosphorus removal wastewater treatment plant. J Environ Eng Sci 2005;4:265-77.

[108] Zeng L, Li X. Nutrient removal from anaerobically digested cattle manure by struvite precipitation. J Environ Eng Sci 2006;5:285-94.

[109] Martí N, Pastor L, Bouzas A, Ferrer J, Seco A. Phosphorus recovery by struvite crystallization in WWTPs: Influence of the sludge treatment line operation. Water Res 2010;44:2371-9.

[110] Yilmazel YD, Demirer GN. Removal and recovery of nutrients as struvite from anaerobic digestion residues of poultry manure. Environ Technol 2011;32:783-94.

[111] Zhang TX, Bowers KE, Harrison JH, Chen SL. Releasing phosphorus from calcium for struvite fertilizer production from anaerobically digested dairy effluent. Water Environ Res 2010;82:3442.

[112] Roeleveld P, Loeffen P, Temmink H, Klapwijk B. Dutch analysis for P-recovery from municipal wastewater. Water Sci Technol 2004;49:191-9.

[113] Lahav O, Telzhensky M, Zewuhn A, Gendel Y, Gerth J, Calmano W, et al. Struvite recovery from municipal-wastewater sludge centrifuge supernatant using seawater NF concentrate as a cheap Mg(II) source. Sep Purif Technol 2013;108:103-10.

[114] Bellier N, Chazarenc F, Comeau Y. Phosphorus removal from wastewater by mineral apatite. Water Res 2006;40:2965-71.

[115] Liedl BE, Bombardiere J, Chatfield JM. Fertilizer potential of liquid and solid effluent from thermophilic anaerobic digestion of poultry waste. Water Sci Technol 2006;53:69-79.

[116] Davis R, Aden A, Pienkos PT. Techno-economic analysis of autotrophic microalgae for fuel production. Appl Energy 2011;88:3524-31.

[117] Stephenson PG, Moore CM, Terry MJ, Zubkov MV, Bibby TS. Improving photosynthesis for algal biofuels: toward a green revolution. Trends Biotechnol 2011;29:615-23.

[118] Cai T, Park SY, Racharaks R, Li Y. Cultivation of Nannochloropsis salina using anaerobic digestion effluent as a nutrient source for biofuel production. Appl Energy 2013;108:486-92.

[119] Sheets JP, Ge X, Park SY, Li Y. Effect of outdoor conditions on Nannochloropsis salina cultivation in artificial seawater using nutrients from anaerobic digestion effluent. Bioresour Technol 2014;152:154-61. 
[120] Wang L, Li Y, Chen P, Min M, Chen Y, Zhu J, et al. Anaerobic digested dairy manure as a nutrient supplement for cultivation of oil-rich green microalgae Chlorella sp. Bioresour Technol 2010;101:2623-8.

[121] Park J, Jin HF, Lim BR, Park KY, Lee K. Ammonia removal from anaerobic digestion effluent of livestock waste using green alga Scenedesmus sp. Bioresour Technol 2010;101:8649-57.

[122] Li X, Hu H, Gan K, Sun Y. Effects of different nitrogen and phosphorus concentrations on the growth, nutrient uptake, and lipid accumulation of a freshwater microalga Scenedesmus sp. Bioresour Technol 2010;101:5494-500.

[123] Wang M, Kuo-Dahab WC, Dolan S, Park C. Kinetics of nutrient removal and expression of extracellular polymeric substances of the microalgae, Chlorella sp. and Micractinium sp., in wastewater treatment. Bioresour Technol 2014;154:131-7.

[124] Zhao YJ, Wang J, Zhang H, Yan C, Zhang Y. Effects of various LED light wavelengths and intensities on microalgae-based simultaneous biogas upgrading and digestate nutrient reduction process. Bioresour Technol 2013;136:461-8.

[125] Hu B, Min M, Zhou W, Du Z, Mohr M, Chen P, et al. Enhanced mixotrophic growth of microalga Chlorella sp. on pretreated swine manure for simultaneous biofuel feedstock production and nutrient removal. Bioresour Technol 2012;126:71-9.

[126] Perez-Garcia O, Escalante FME, de-Bashan LE, Bashan Y. Heterotrophic cultures of microalgae: Metabolism and potential products. Water Res 2011;45:11-36.

[127] Fortier MOP, Sturm BSM. Geographic analysis of the feasibility of collocating algal biomass production with wastewater treatment plants. Environ Sci Technol 2012;46:11426-34.

[128] Woertz I, Feffer A, Lundquist T, Nelson Y. Algae grown on dairy and municipal wastewater for simultaneous nutrient removal and lipid production for biofuel feedstock. J Environ Eng 2009; 135:1115-22.

[129] Day JG, Thomas NJ, Achilles-Day UEM, Leakey RJG. Early detection of protozoan grazers in algal biofuel cultures. Bioresour Technol 2012;114:715-9.

[130] Singh M, Reynolds DL, Das KC. Microalgal system for treatment of effluent from poultry litter anaerobic digestion. Bioresour Technol 2011;102:10841-8.

[131] Bjornsson WJ, Nicol RW, Dickinson KE, Mcginn PJ. Anaerobic digestates are useful nutrient sources for microalgae cultivation: functional coupling of energy and biomass production. J Appl Phycol 2013;25:1523-8.

[132] Yuan X, Wang M, Park C, Sahu AK, Ergas SJ. Microalgae growth using high-strength wastewater followed by anaerobic co-digestion. Water Environ Res 2012;84:396-404.

[133] Cai T, Ge X, Park SY, Li Y. Comparison of Synechocystis sp. PCC6803 and Nannochloropsis salina for lipid production using artificial seawater and nutrients from anaerobic digestion effluent. Bioresour Technol 2013;144:255-60. 
[134] Ruiz-Martinez A, Garcia NM, Romero I, Seco A, Ferrer J. Microalgae cultivation in wastewater: Nutrient removal from anaerobic membrane bioreactor effluent. Bioresour Technol 2012;126:247-53.

[135] Chen R, Li R, Deitz L, Liu Y, Stevenson RJ, Liao W. Freshwater algal cultivation with animal waste for nutrient removal and biomass production. Biomass Bioenergy 2012;39:128-38.

[136] Chaiklahan R, Chirasuwan N, Siangdung W, Paithoonrangsarid K, Bunnag B. Cultivation of Spirulina platensis using pig wastewater in a semi-continuous process. J Microbiol Biotechnol 2010;20:609-14.

[137] Day JG, Slocombe SP, Stanley MS. Overcoming biological constraints to enable the exploitation of microalgae for biofuels. Bioresour Technol 2012;109:245-51.

[138] Zhao B, Ma J, Zhao Q, Laurens L, Jarvis E, Chen S, et al. Efficient anaerobic digestion of whole microalgae and lipid-extracted microalgae residues for methane energy production. Bioresour Technol 2014;161:423-30.

[139] Desk top study on digestate enhancement and treatment. Enhancement and treatment of digestates from anaerobic digestion. WRAP; 2012.

[140] Lin L, Yang L, Xu F, Michel FC, Li Y. Comparison of solid-state anaerobic digestion and composting of yard trimmings with effluent from liquid anaerobic digestion. Bioresour Technol 2014;169:439-46.

[141] Sweeten JM, Auvermann BW. Composting manure and sludge. Agrilife Extension 2006;479:1-7.

[142] Das KC. Co-composting of alkaline tissue digester effluent with yard trimmings. Waste Manage 2008;28:1785-90.

[143] Franke-Whittle IH, Confalonieri A, Insam H, Schlegelmilch M, Korner I. Changes in the microbial communities during co-composting of digestates. Waste Manage 2014;34:632-41.

[144] Troy SM, Nolan T, Kwapinski W, Leahy JJ, Healy MG, Lawlor PG. Effect of sawdust addition on composting of separated raw and anaerobically digested pig manure. J Environ Manage 2012;111:70-7.

[145] Provenzano MR, Malerba AD, Pezzolla D, Gigliotti G. Chemical and spectroscopic characterization of organic matter during the anaerobic digestion and successive composting of pig slurry. Waste Manage 2014;34:653-60.

[146] Romero C, Ramos P, Costa C, Marquez MC. Raw and digested municipal waste compost leachate as potential fertilizer: comparison with a commercial fertilizer. J Clean Prod 2013; 59:73-8.

[147] Kratzeisen M, Starcevic N, Martinov M, Maurer C, Müller J. Applicability of biogas digestate as solid fuel. Fuel 2010;89:2544-8.

[148] Gnanendra PM, Ramesha DK, Dasappa S. Preliminary investigation on the use of biogas sludge for gasification. Int J Sustain Energy 2012;31:251-67. 
[149] Cao Y, Pawlowski A. Sewage sludge-to-energy approaches based on anaerobic digestion and pyrolysis: Brief overview and energy efficiency assessment. Renew Sustain Energy Rev 2012;16:1657-65.

[150] Li Y, Zhang R, He Y, Zhang C, Liu X, Chen C, et al. Anaerobic co-digestion of chicken manure and corn stover in batch and continuously stirred tank reactor (CSTR). Bioresour Technol 2014;156:342-7.

[151] Teater C, Yue Z, MacLellan J, Liu Y, Liao W. Assessing solid digestate from anaerobic digestion as feedstock for ethanol production. Bioresour Technol 2011;102:1856-62.

[152] Yue Z, Teater C, MacLellan J, Liu Y, Liao W. Development of a new bioethanol feedstock Anaerobically digested fiber from confined dairy operations using different digestion configurations. Biomass Bioenergy 2011;35:1946-53.

[153] MacLellan J, Chen R, Kraemer R, Zhong Y, Liu Y, Liao W. Anaerobic treatment of lignocellulosic material to co-produce methane and digested fiber for ethanol biorefining. Bioresour Technol 2013;130:418-23.

[154] Yue Z, MacLellan J, Liu Y, Liao W. Effects of corn stover as carbon supplement on an integrated anaerobic digestion and ethanol fermentation process. J Renew Sustain Energy 2013;5:1-9.

[155] Elumalai S, Roa-Espinosa A, Markley JL, Runge TM. Combined sodium hydroxide and ammonium hydroxide pretreatment of post-biogas digestion dairy manure fiber for cost effective cellulosic bioethanol production. Sustain Chem Process 2014;2:12.

[156] Kirk DM. Making Digesters Work: The economics of bedding and co-feeding. 2011 Midwest Manure Summit, Conference proceedings; 2011.

[157] Alexander R. Digestate utilization in the U.S. Biocycle Magazine; 53 ed. 2012. p. 56. http://www.biocycle.net/2012/01/12/digestate-utilization-in-the-u-s/

[158] Taruya T, Okuno N, Kanaya K. Reuse of sewage sludge as raw material of Portland cement in Japan. Water Sci and Technol 2002;46:255-8.

[159] Tyagi VK, Lo SL. Sludge: A waste or renewable source for energy and resources recovery? Renew Sustain Energy Rev 2013;25:708-28.

[160] Murray A, Horvath A, Nelson KL. Hybrid life-cycle environmental and cost inventory of sewage sludge treatment and end-use scenarios: A case study from China. Environ Sci Technol 2008;42:3163-9.

[161] Carballa M, Omil F, Ternes T, Lema JM. Fate of pharmaceutical and personal care products (PPCPs) during anaerobic digestion of sewage sludge. Water Res 2007;41:2139-50.

[162] Padhye LP, Huang CH. Occurrence and fate of pharmaceutical and personal care products (PPCPs) in urban wastewater treatment plants. Abstracts of Papers of the American Chemical Society $2012 ; 243$. 
[163] Mitchell SM, Ullman JL, Teel AL, Watts RJ, Frear C. The effects of the antibiotics ampicillin, florfenicol, sulfamethazine, and tylosin on biogas production and their degradation efficiency during anaerobic digestion. Bioresour Technol 2013;149:244-52.

[164] Carballa M, Manterola G, Larrea L, Ternes T, Omil F, Lema JM. Influence of ozone pretreatment on sludge anaerobic digestion: Removal of pharmaceutical and personal care products. Chemosphere 2007;67:1444-52.

[165] Weemaes MPJ, Verstraete WH. Evaluation of current wet sludge disintegration techniques. J Chem Technol Biotechnol 1998;73:83-92.

[166] Martin J, Santos JL, Aparicio I, Alonso E. Pharmaceutically active compounds in sludge stabilization treatments: Anaerobic and aerobic digestion, wastewater stabilization ponds and composting. Sci Tot Environ 2014; 503-504:97-104.

[167] Samaras VG, Stasinakis AS, Thomaidis NS, Mamais D, Lekkas TD. Fate of selected emerging micropollutants during mesophilic, thermophilic and temperature co-phased anaerobic digestion of sewage sludge. Bioresour Technol 2014;162:365-72.

[168] Ejlertsson J, Svensson BH. Degradation of bis(2-ethylhexyl)phthalate constituents under methanogenic conditions. Biodegrad 1997;7:501-6.

[169] Itakura T, Airey DW, Leo CJ. The diffusion and sorption of volatile organic compounds through kaolinitic clayey soils. J Contam Hydro 2003;65:219-43.

[170] Levén L, Nyberg K, Korkea-Aho L, Schnürer A. Phenols in anaerobic digestion processes and inhibition of ammonia oxidising bacteria (AOB) in soil. Sci Total Environ 2006;364:229-38.

[171] Muller M, Combalbert S, Delgenes N, Bergheaud V, Rocher V, Benoît P, et al. Occurrence of estrogens in sewage sludge and their fate during plant-scale anaerobic digestion. Chemosphere 2010;81:65-71.

[172] Chase DA, Karnjanapiboonwong A, Fang Y, Cobb GP, Morse AN, Anderson TA. Occurrence of synthetic musk fragrances in effluent and non-effluent impacted environments. Sci Total Environ 2012;416:253-60.

[173] Carballa M, Omil F, Alder AC, Lema JM. Comparison between the conventional anaerobic digestion of sewage sludge and its combination with a chemical or thermal pre-treatment concerning the removal of pharmaceuticals and personal care products. Water Sci Technol 2006;53:109-17.

[174] Gottschall N, Topp E, Metcalfe C, Edwards M, Payne M, Kleywegt S, et al. Pharmaceutical and personal care products in groundwater, subsurface drainage, soil, and wheat grain, following a high single application of municipal biosolids to a field. Chemosphere 2012;87:194-203.

[175] Enright AM, Collins G, O'Flaherty V. Low-temperature anaerobic biological treatment of toluene-containing wastewater. Water Res 2007;41:1465-72.

[176] Lozano N, Rice CP, Ramirez M, Torrents A. Fate of triclosan in agricultural soils after biosolid applications. Chemosphere 2010;78:760-6. 
[177] Narumiya M, Nakada N, Yamashita N, Tanaka H. Phase distribution and removal of pharmaceuticals and personal care products during anaerobic sludge digestion. J Hazard Mater 2013;260:305-12.

[178] Alfa MI, Adie DB, Igboro SB, Oranusi US, Dahunsi SO, Akali DM. Assessment of biofertilizer quality and health implications of anaerobic digestion effluent of cow dung and chicken droppings. Renew Energy 2014;63:681-6.

[179] Fu B, Jiang Q, Liu H, Liu H. Occurrence and reactivation of viable but non-culturable E-coli in sewage sludge after mesophilic and thermophilic anaerobic digestion. Biotechnol Lett 2014;36:273-9.

[180] Resende JA, Silva VL, de Oliveira TLR, Fortunato SD, Carneiro JD, Otenio MH, et al. Prevalence and persistence of potentially pathogenic and antibiotic resistant bacteria during anaerobic digestion treatment of cattle manure. Bioresour Technol 2014;153:284-91.

[181] Chen YC, Murthy SN, Hendrickson D, Higgins MJ. Do alternate bacterial indicators and pathogens increase after centrifuge dewatering of anaerobically digested biosolids? Water Environ Res 2011;83:2057-66.

[182] Erkan M, Sanin FD. Can sludge dewatering reactivate microorganisms in mesophilically digested anaerobic sludge? Case of belt filter versus centrifuge. Water Res 2013;47:428-38.

[183] Walsh JJ, Rousk J, Edwards-Jones G, Jones DL, Williams AP. Fungal and bacterial growth following the application of slurry and anaerobic digestate of livestock manure to temperate pasture soils. Biol Fertil Soils 2012;48:889-97.

[184] Campos E, Almirall M, Mtnez-Almela J, Palatsi J, Flotats X. Feasibility study of the anaerobic digestion of dewatered pig slurry by means of polyacrylamide. Bioresour Technol 2008; 99:38795. 